\title{
A review on the morphology, molecular characterization, morphogenesis and pathogenesis of white spot syndrome virus
}

\author{
C M Escobedo-Bonilla ${ }^{1,2^{\star}}$, V Alday-Sanz ${ }^{3}$, M Wille $^{1}$, P Sorgeloos ${ }^{1}$, M B Pensaert $^{2}$ \\ and $\mathrm{H}$ J Nauwynck ${ }^{2}$
}

1 Laboratory of Aquaculture and Artemia Reference Center, Faculty of Bioscience Engineering, Ghent University, Ghent, Belgium

2 Laboratory of Virology, Faculty of Veterinary Medicine, Ghent University, Ghent, Belgium

3 Aquatic Animal Health, Dendermonde, Belgium

\begin{abstract}
Since it first appeared in 1992, white spot syndrome virus (WSSV) has become the most threatening infectious agent in shrimp aquaculture. Within a decade, this pathogen has spread to all the main shrimp farming areas and has caused enormous economic losses amounting to more than seven billion US dollars. At present, biosecurity methods used to exclude pathogens in shrimp farms include disinfecting ponds and water, preventing the entrance of animals that may carry infectious agents and stocking ponds with specific pathogen-free post-larvae. The combination of these practices increases biosecurity in shrimp farming facilities and may contribute to reduce the risk of a WSSV outbreak. Although several control methods have shown some efficacy against WSSV under experimental conditions, no therapeutic products or strategies are available to effectively control WSSV in the field. Furthermore, differences in virulence and clinical outcome of WSSV infections have been
\end{abstract}

Correspondence H J Nauwynck, Laboratory of Virology, Faculty of Veterinary Medicine, Ghent University, Salisburylaan 133, B-9820 Merelbeke, Belgium

(e-mail: Hans.Nauwynck@UGent.be)

"Present address: Centro de Investigaciones Biológicas del Noroeste, S.C. Unidad Sonora, Centenario Norte no. 53, Colonia

(C) 2008 The Authors. Journal compilation (C) 2008

Blackwell Publishing Ltd reported. The sequencing and characterization of different strains of WSSV has begun to determine aspects of its biology, virulence and pathogenesis. Knowledge on these aspects is critical for developing effective control methods. The aim of this review is to present an update of the knowledge generated so far on different aspects of WSSV organization, morphogenesis, pathology and pathogenesis.

Keywords: morphogenesis, pathogenesis, review, shrimp aquaculture, viral diseases, white spot syndrome virus.

\section{Introduction}

In 1992, a new virus appeared in shrimp farms in northern Taiwan causing disease and massive mortality (Chou, Huang, Wang, Chiang \& Lo 1995). In late 1993, the viral agent was first isolated from an outbreak in Japan (Inouye, Miwa, Oseko, Nakano, Kimura, Momoyama \& Hiraoka 1994) and within a few years this new pathogenic agent spread to several shrimp farming countries (Flegel 1997; Anonymous 2003). At first, it was thought that different viral agents had simultaneously appeared in different regions and each were given a specific name: hypodermal and haematopoietic necrosis baculovirus (HHNBV) (see Durand, Lightner, Nunan, Redman, Mari \& Bonami 
1996), third Penaeus monodon non-occluded baculovirus (PmNOB III) (see Wang, Lo, Leu, Chou, Yeh, Chou, Tung, Chang, Su \& Kou 1995; Karunasagar, Otta \& Karunasagar 1997), rodshaped nuclear virus of Marsupenaeus japonicus (RV-PJ) (Inouye et al. 1994; Inouye, Yamano, Ikeda, Kimura, Nakano, Momoyama, Kobayashi \& Miyajima 1996), penaeid rod-shaped DNA virus (see Venegas, Nonaka, Mushiake, Nishizawa \& Muroga 2000), systemic ectodermal and mesodermal baculovirus (Wongteerasupaya, Vickers, Sriurairatana, Nash, Akarajamorn, Boonsaeng, Panyim, Tassanakajon, Withyachumnarnkul \& Flegel 1995; Sahul-Hameed, Anilkumar, Raj \& Jayaraman 1998) or white spot baculovirus (Chou et al. 1995; Lightner 1996). Later, it was recognized that a single viral agent was responsible for these reports. Eventually an informal consensus was reached to call it white spot syndrome virus (WSSV). This pathogen is now recognized as the most serious for shrimp aquaculture worldwide. The reports of WSSV outbreaks in various shrimp farming countries are presented in Table 1 .
In China, production losses of $80 \%$ of farmed shrimp were attributed to WSSV (Zhan, Wang, Fryer, Yu, Fukuda \& Meng 1998) (Fig. 1a) and in Ecuador, the impact of WSSV on farmed shrimp production was also disastrous (Fig. 1b) (FAO 2006). The spread of WSSV to other shrimp farming countries threatens the development of shrimp aquaculture. In 2000, crabs and crayfish in Australia were apparently found WSSV-positive using polymerase chain reaction (PCR) primers but later these results were proven to be false-positives (Claydon, Cullen \& Owens 2004). Australia remains at risk of a WSSV outbreak, given its proximity to Southeast Asia where the pathogen is endemic (Chang, Su, Chen, Lo, Kou \& Liao 1999; Chang, Su, Chen \& Liao 2003). It is possible that some Asian crustaceans carrying WSSV may reach Australia and spread to shrimp farming areas (Claydon et al. 2004). In 2002, WSSV was found in wild crustaceans off the French Mediterranean coast (see Marks 2005). The presence of WSSV in the Mediterranean may hamper the development of shrimp aquaculture, especially in North African

Table 1 Chronology of white spot syndrome virus outbreaks in shrimp farming countries in Asia and America

\begin{tabular}{lll}
\hline $\begin{array}{l}\text { Year first } \\
\text { reported }\end{array}$ & Country & Reference \\
\hline 1992 & Taiwan & Chou et al. 1995 \\
1993 & China, Japan, Korea & Zhan et al. 1998; Inouye et al. 1994; Park et al. 1998 \\
1994 & Thailand, India, Bangladesh & Lo et al. 1996a; Karunasagar et al. 1997; Mazid \& Banu 2002 \\
1995 & USA & Lightner 1996; Wang et al. 1999a \\
1996 & Indonesia, Malaysia, Sri Lanka & Durand et al. 1996; Kasornchandra et al. 1998; Rajan et al. 2000 \\
1997 & Vietnam & Bondad-Reantaso et al. 2001 \\
1998 & Peru & Rosenberry 2001 \\
1999 & Philippines, Ecuador, Colombia, Panamá, & Magbanua et al. 2000; Bondad-Reantaso et al. 2001; \\
$1999-2000$ & Honduras, Nicaragua, Guatemala, Belice & Hossain et al. 2001; Wu et al. 2001 \\
2002 & México & Bondad-Reantaso et al. 2001 \\
2005 & France, Iran & Dieu et al. 2004; Marks 2005 \\
& Brazil & APHIS-USDA 2005 \\
\hline
\end{tabular}

(C) 2008 The Authors. Journal compilation (C) 2008 Blackwell Publishing Ltd
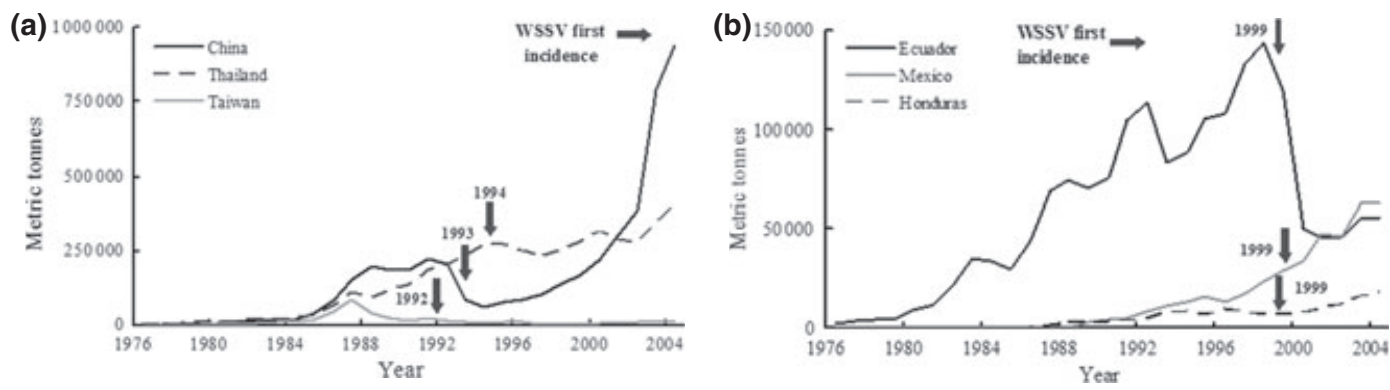

Figure 1 Impact of white spot syndrome virus on farmed-shrimp production in (a) Asian and (b) American countries (FAO 2006). Arrows indicate year of first outbreak reported for each country. 
countries. The introduction of WSSV-infected organisms to the areas where the pathogen was previously unknown may be possible through ballast water from cargo ships (Flegel \& Fegan 2002) or even frozen commodities (Durand, Tang \& Lightner 2000).

\section{Morphology of WSSV}

White spot syndrome virus is a bacilliform, nonoccluded enveloped virus (Chou et al. 1995; Wang et al. 1995; Wongteerasupaya et al. 1995). Intact enveloped virions range between 210 and $380 \mathrm{~nm}$ in length and $70-167 \mathrm{~nm}$ in maximum width (Chang, Lo, Wang \& Kou 1996; Flegel \& AldaySanz 1998; Park, Lee, Lee \& Lee 1998; Rajendran, Vijayan, Santiago \& Krol 1999). A tail-like appendage at one end of the WSSV virion is sometimes observed in negatively stained electron micrographs (Wongteerasupaya et al. 1995; Durand et al. 1996) (Fig. 2a, b).

The viral envelope is $6-7 \mathrm{~nm}$ thick and is a lipidic, trilaminar membranous structure with two electron-transparent layers divided by an electronopaque layer (Wongteerasupaya et al. 1995; Durand, Lightner, Redman \& Bonami 1997; Nadala, Tapay \& Loh 1998).

The nucleocapsid is located inside the envelope and is a stacked ring structure composed of globular protein subunits of $10 \mathrm{~nm}$ in diameter arranged in 14-15 vertical striations located every $22 \mathrm{~nm}$ along the long axis, giving it a cross-hatched appearance (Durand et al. 1997; Nadala \& Loh 1998). When released from the envelope, the nucleocapsid increases in length indicating that it is tightly packed within the virion. The size of the nucleo- capsid varies from isolate to isolate and ranges between 180 and $420 \mathrm{~nm}$ in length and 54-85 nm in width, with a 6-nm thick external wall (Kasornchandra, Boonyaratpalin \& Itami 1998; SahulHameed et al. 1998; Rajendran et al. 1999).

A highly electrondense core comprised of the DNA binding protein VP15 and the viral DNA is found inside the nucleocapsid (Durand et al. 1997; Wang, White, Redman \& Lightner 1999b; van Hulten, Witteveldt, Peters, Kloosterboer, Tarchini, Fiers, Sandbrink, Klein-Langhorst \& Vlak 2001a).

\section{Structural proteins}

More than 40 WSSV proteins have been characterized (Table 2). Some non-structural proteins are probably involved in transcriptional regulation (VP9) (Liu, Wu, Song, Sivaraman \& Hew 2006), virus proliferation (WSV021) (Zhu, Ding \& Yang 2007) and/or regulation of DNA replication (WSV477) (Han, Xu \& Zhang 2007). At least 38 structural proteins have been located in the WSSV virion. Of these, 21 have been found in the envelope, 10 in the nucleocapsid and five in the tegument (a putative structure located between the envelope and nucleocapsid).

A cell attachment motif that suggests a role in viral entry has been found in the envelope proteins VP31, VP110 and VP281 (Huang, Zhang, Lin, Xu, Hu \& Hew 2002a; Tsai, Wang, Leu, Hsiao, Wang, Kou \& Lo 2004; Li, Xie \& Yang 2005a; Xie, Xu \& Yang 2006), the tegument protein VP36A and the nucleocapsid proteins VP664 (Tsai et al. 2004; Leu, Tsai, Wang, Wang, Wang, Kou \& Lo 2005) and VP136A (Tsai et al. 2004; Xie et al. 2006). Other proteins such as VP28, VP39B, VP41A,
(C) 2008 The Authors. Journal compilation (C) 2008

Blackwell Publishing Ltd (a)

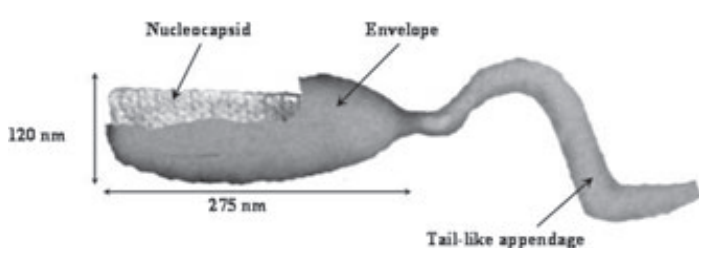

(b)

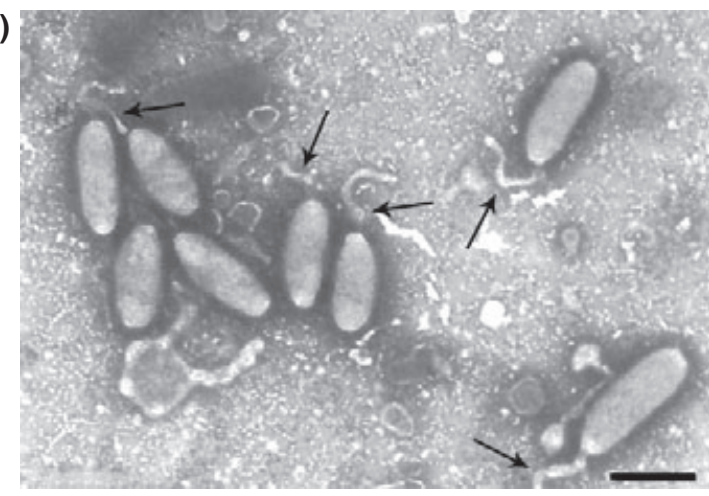

Figure 2 (a) Morphology of the white spot syndrome virus (WSSV) virion. (b) Electron micrograph showing WSSV virions with the tail-like appendage (black arrows) (bar $=250 \mathrm{~nm}$ ) (picture from Durand et al. 1996). 
Table 2 List of white spot syndrome virus (WSSV) proteins so far characterized

\begin{tabular}{|c|c|c|c|c|c|}
\hline Protein name & $\begin{array}{l}\text { Genbank } \\
\text { accession number }\end{array}$ & $\begin{array}{l}\text { Size (aminoacid } \\
\text { residues) }\end{array}$ & $\begin{array}{l}\text { Apparent } \\
\text { size }(k D a)\end{array}$ & $\begin{array}{l}\text { Putative } \\
\text { function }\end{array}$ & $\begin{array}{l}\text { Location in WSSV } \\
\text { virion (references) }\end{array}$ \\
\hline VP9 & 2GJIA & 79 & 9 & Transcriptional & Non-structural ${ }^{18}$ \\
\hline VP11 & AAL89262 & 433 & 11 & Unknown & Not determined ${ }^{8}$ \\
\hline VP12A (VP95) & AF402996 & 95 & 11 & Structural & Tegument $^{8,} 9,21$ \\
\hline VP12B (VP68) & AF411464 & 68 & 7 & Structural & Envelope $^{8,12,13}$ \\
\hline VP13A & AAL89207 & 100 & 13 & Energy metabolism & Not determined ${ }^{8}$ \\
\hline VP13B (VP16) & AAL89245 & 117 & 13 & Structural & Envelope $^{21}$ \\
\hline VP14 & AAL89217 & 97 & 11 & Structural & Envelope $^{21}$ \\
\hline VP15 & AAL89137 & 80 & 15 & DNA binding protein & Nucleocapsid/core 8,11 \\
\hline VP19 & AAL89341 & 121 & 19 & Structural & Envelope $^{8,9,11}$ \\
\hline WSV021 & AAL33025 & 200 & 23 & Regulation virus replication & Non-structural $^{19}$ \\
\hline VP22 (VP184) & AAL89227 & 891 & 100 & Unknown & Not determined ${ }^{8}$ \\
\hline VP24 (VP208) & DQ902656 & 208 & 24 & Structural & Nucleocapsid $^{8,10,13}$ \\
\hline VP26 & EF534253 & 204 & 26 & Structural & Tegument $^{8,10}$ \\
\hline VP28 & EF534254 & 204 & 28 & Structural & Envelope $^{8,}, 9,10$ \\
\hline VP31 & AY897235 & 261 & 31 & Cell attachment & Envelope ${ }^{6,8,9}$ \\
\hline VP32 & AAL89121 & 278 & 32 & Structural & Envelope $^{8,21}$ \\
\hline VP35 & AY325896 & 228 & 26 & Structural & Nucleocapsid ${ }^{1}$ \\
\hline VP36A & AAL89002 & 297 & 36 & Cell attachment & Tegument $^{8,9}$ \\
\hline VP33 (VP281) & EF534251 & 281 & 32 & Cell attachment & Envelope $^{2,} 8,12,21$ \\
\hline VP38A & AAL89182 & 309 & 35 & Structural & Envelope $^{8,9,21}$ \\
\hline VP38B & AAL89317 & 321 & 38 & Endonuclease & Not determined ${ }^{8}$ \\
\hline VP39A & AAL89230 & 419 & 39 & Structural & Tegument $^{8,9}$ \\
\hline VP39B & AY884234 & 283 & 32 & Structural & Envelope $^{8,15,21}$ \\
\hline VP41A (VP292) & AF411636 & 292 & 33 & Structural & Envelope $^{2,8,13}$ \\
\hline VP41B (VP300) & AF403003 & 300 & 34 & Structural & Envelope $^{8,21}$ \\
\hline VP51A & AAL89162 & 486 & 51 & Structural & Envelope $^{8,17,21}$ \\
\hline VP51B (VP384) & AAL89179 & 384 & 46 & Structural & Envelope $^{8,9,21}$ \\
\hline VP51C (VP466) & AAL89232 & 466 & 50 & Structural & Nucleocapsid $3,8,12$ \\
\hline VP53A (VP150) & AAL88935 & 1301 & 144 & Structural & Envelope $8,9,21$ \\
\hline VP53B & AAL89039 & 968 & 53 & Signal transduction pathway & Not determined ${ }^{8}$ \\
\hline VP53C & AAL89192 & 489 & 53 & Unknown & Not determined ${ }^{8}$ \\
\hline VP55 (VP448) & AAL88919 & 448 & 55 & Unknown & Not determined ${ }^{8}$ \\
\hline VP60A (VP56) & AAL89249 & 465 & 60 & Structural & Envelope $^{21}$ \\
\hline VP60B (VP544) & AAL89342 & 544 & 60 & Adenovirus fibre-like protein & Nucleocapsid $8,9,13,21$ \\
\hline VP75 & AAL89256 & 786 & 75 & Structural & Nucleocapsid ${ }^{16}$ \\
\hline VP76 (VP73) & AAL89143 & 675 & 76 & Class 1 cytokine receptor & Nucleocapsid $4,8,17,21$ \\
\hline VP90 & AAL89251 & 856 & 96 & Structural & Envelope $^{21}$ \\
\hline VP95 & AAL89370 & 800 & 89 & Structural & Tegument $^{21}$ \\
\hline VP110 & AAL88960 & 972 & 110 & Cell attachment & Envelope $^{8,21}$ \\
\hline VP124 & AAL89139 & 1194 & 124 & Structural & Envelope $^{8,14,21}$ \\
\hline VP136A & AAL89194 & 1219 & 136 & Cell attachment & Nucleocapsid $^{8,21}$ \\
\hline VP136B & AAL89392 & 1243 & 136 & Unknown & Not determined ${ }^{8}$ \\
\hline VP180 (VP1684) & AAL88920 & 1684 & 169 & Collagen-like protein & Envelope $^{8}$ \\
\hline VP187 & AAL89132 & 1606 & 174 & Structural & Envelope $e^{7,21}$ \\
\hline VP190 & AAL33291 & 1565 & 174 & Structural & Nucleocapsid ${ }^{21}$ \\
\hline WSV477 & DQ121373 & 208 & 30 & DNA replication & Non-structural ${ }^{20}$ \\
\hline VP664 & AAL89287 & 6077 & 664 & Cell attachment & Nucleocapsid $5,8,9$ \\
\hline VP800 & AAL02264 & 800 & 90 & Unknown & Not determined ${ }^{8}$ \\
\hline
\end{tabular}

References: ${ }^{1}$ Chen et al. 2002b; ${ }^{2}$ Huang et al. 2002a,b, 2005; ${ }^{5}$ Leu et al. 2005; ${ }^{6} \mathrm{Li}$ et al. 2005a, 2006b,a, ${ }^{8}$ Tsai et al. 2004, 2006; ${ }^{10}$ van Hulten et al. 2000b; ${ }^{11}$ van Hulten et al. 2002; ${ }^{12} \mathrm{Wu}$ et al. 2005; ${ }^{13} \mathrm{Zhang}$ et al. 2004; ${ }^{14} \mathrm{Z}$ hu et al. 2005; ${ }^{15} \mathrm{Zhu}$ et al. 2006; ${ }^{16} \mathrm{Xiao}$ et al. 2006; ${ }^{17} \mathrm{Wu} \& \mathrm{Yang} 2006$; ${ }^{18}$ Liu et al. 2006; ${ }^{19} \mathrm{Zhu}$ et al. 2007; ${ }^{20} \mathrm{Han}$ et al. 2007; ${ }^{21}$ Xie et al. 2006;.

(C) 2008 The Authors. Journal compilation (C) 2008 Blackwell Publishing Ltd
Yang 2005; Li, Zhu, Xie \& Yang 2006a; Xie et al. 2006; Zhu, Li \& Yang 2006); whereas the proteins VP35 (Chen, Leu, Huang, Chou, Chen, Wang, Lo \& Kou 2002a), VP466 (Huang, Zhang, Lin, Xu \& Hew 2002b), VP15 (van Hulten et al. 2002), VP51, VP76 (Wu \& Yang 2006) and others (Xiao, Zhang, Dai, Yuan, Wang, Zhang, Xu \& Dai 2006)

have been located in the nucleocapsid and may have
VP41B, VP51A, VP51B, VP68, VP124, VP150, VP187, VP281, VP292 and a collagen-like protein (Li, Chen \& Yang 2004) have been located in the envelope (van Hulten, Witteveldt, Snippe \& Vlak 2001b; van Hulten et al. 2001a; Huang et al. 2002a; van Hulten, Reijns, Vermeesch, Zandbergen \& Vlak 2002; Zhang, Huang, Tang, Zhuang \& Hew 2004; Wu, Wang \& Zhang 2005; Zhu, Xie \& 
different putative functions (van Hulten et al. 2001a; Yang, He, Lin, Li, Pan, Zhang \& Xu 2001).

In vivo neutralization assays using antibodies against different structural proteins showed a significant delay of shrimp mortality, indicating that proteins such as VP28 (van Hulten et al. 2001b; Yi, Wang, Qi, Yao, Qian \& Hu 2004), VP68, VP281, VP466 (Wu et al. 2005) and even VP24 (Xie \& Yang 2006), might have an important role in virus penetration. Recently, a $25-\mathrm{kDa}$ membrane protein from shrimp haemocytes was found to bind to recombinant VP28 or WSSV virions. This protein has high homology to the small GTP-binding protein Rab7. In vivo neutralization assays with anti-Rab7 antibody inhibited the binding of WSSV virions to the cells and significantly reduced mortality upon WSSV challenge (Sritunyalucksana, Wannapapho, Lo \& Flegel 2006). In crayfish, neutralization assays with the envelope proteins VP31, VP33 (also known as VP36B) and the tegument protein VP36A strongly inhibited WSSV replication, indicating that these proteins have an important role in infection $(\mathrm{Li}$, Yuan, Cai, Gu \& Shi 2006b).

The role of different WSSV proteins in infection has recently been studied by RNA interference. In Litopenaeus vannamei $(=P$. vanname $i)$, long doublestranded (ds) RNA corresponding to VP19 induced a specific antiviral response that inhibited WSSV infection and significantly reduced mortality (Robalino, Bartlett, Shepard, Prior, Jaramillo, Scura, Chapman, Gross, Browdy \& Warr 2005). In Fenneropenaeus chinensis $(=P$. chinensis $)$, long $\mathrm{d}$ RNA corresponding to VP28, VP281, WSSV protein kinases $(\mathrm{PK})$ and an unrelated ds RNA from the green fluorescence protein (GFP) induced higher survival of WSSV-challenged shrimp. The highest survival rates were found in shrimp treated with ds RNA from VP28 and PK (Kim, Kosuke, Nam, Kim \& Kim 2007). A complete inhibition of a WSSV infection in shrimp was achieved by three consecutive injections of small short interfering RNA (siRNA) against VP28 in Marsupenaeus japonicus (=P. japonicus) (Xu, Han \& Zhang 2007).

\section{Genome and classification}

The WSSV genome is a circular, ds DNA molecule with an A+T content of 59\% homogeneously distributed. The genome size varies according to the viral isolate [Thailand $293 \mathrm{kbp}$ (see Fig. 3),

(C) 2008 The Authors. Journal compilation (C) 2008

Blackwell Publishing Ltd

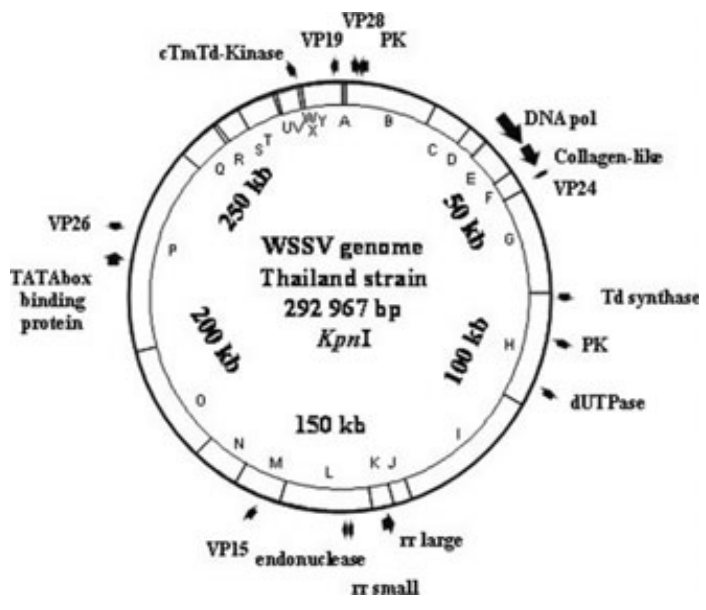

Figure 3 General structure of the white spot syndrome virus genome (Thailand strain).

2001a; Yang et al. 2001; Chen, Wang, Huang, Peng, Chen, Lin, Chen, Dai, Yu \& Wang 2002b).

This viral genome is one of the largest sequenced so far, being only smaller than a huge virus (mimivirus) infecting an amoeba (1 $181404 \mathrm{bp}$ ), a canarypox (359 $853 \mathrm{bp}$ ), a virus from the brown alga Ectocarpus siliculosus (335 593 bp) and a virus from Paramecium bursaria (PBCV-1) (330 743 bp) (van Hulten et al. 2001b; Raoult, Audic, Robert, Abergel, Renesto, Ogata, La Scola, Suzan \& Claverie 2004; http://www.giantvirus.org).

Sequence analysis shows that the WSSV genome contains between 531 and 684 open reading frames (ORFs) with an ATG initiation codon. Of these, 181-184 ORFs are likely to encode functional proteins with sizes between 51 and 6077 aminoacids, which represent $92 \%$ of the genetic information contained in the genome (van Hulten et al. 2001b; Yang et al. 2001). About 21-29\% of such ORFs have been shown to encode WSSV proteins or share identity with other known proteins. These proteins include enzymes involved in nucleic acid metabolism and DNA replication such as DNA polymerase (Chen et al. 2002b), a non-specific nuclease (Witteveldt, van Hulten \& Vlak 2001; Li, Lin \& Yang 2005b), a small and a large subunit of ribonucleotide reductase (van Hulten, Tsai, Schipper, Lo, Kou \& Vlak 2000a; Tsai, Lo, Van Hulten, Tzeng, Chou, Huang, Wang, Lin, Vlak \& Kou 2000a), thymidine kinase, thymidylate kinase, a chimeric thymidine-thymidylate kinase (Tsai, Yu, Tzeng, Leu, Chou, Huang, Wang, Lin, Kou \& Lo 2000b), a thymidylate synthase ( $\mathrm{Li}$ et al. 2004), a dUTPase (Liu \& Yang 2005) and two PK (van 
Hulten \& Vlak 2001; van Hulten et al. 2001b; Yang et al. 2001). Other proteins with a putative function include a collagen-like protein ( $\mathrm{Li}$ et al. 2004), flagellin, a chitinase, a pupal cuticle-like protein, a cell surface flocculin, a kunitz-like proteinase inhibitor, a class 1 cytokine receptor, a sno-like peptide and a chimeric anti-apoptotic protein (van Hulten et al. 2001b; Yang et al. 2001; Marks 2005). Three ORFs (151, 366 and 427 of the Thailand isolate) may encode putative proteins involved in WSSV latency (Khadijah, Neo, Hossain, Miller, Mathavan \& Kwang 2003).

Recently, it was found that WSSV also has three immediate early (IE) genes (ORFs 126, 242 and 418 of the Taiwan isolate). These genes are transcribed independently of any viral protein synthesized de novo by the host cell machinery and are directly expressed in vitro. These IE genes may be important to determine host range and also can function as regulatory trans-acting factors during infection (Liu, Chang, Wang, Kou \& Lo 2005).

Transcriptional analysis of genes coding for proteins required in DNA replication and nucleotide metabolism are synthesized early during virus replication. Early transcribed WSSV genes in general have a TATA box 20-30 nucleotides upstream of the transcription initiation site (TIS) (A/C)TCANT (Chen et al. 2002b; Liu et al. 2005; Marks 2005). Structural proteins are synthesized later during infection and generally have a degenerate TIS motif (A/TNAC/G) located 25 nucleotides downstream of an $\mathrm{A} / \mathrm{T}$ rich region; which is similar to the TIS motif found in arthropods (Tsai et al. 2004; Marks 2005). WSSV has an internal ribosome entry site (IRES) element. WSSV IRES efficiently co-expressed a glutathione S-transferase and a GFP protein arranged in a dicistronic mRNA in vitro (Han \& Zhang 2006).

Sequence analysis of the DNA polymerase and the organization of several ORFs known to encode WSSV structural proteins were different from those of known baculoviruses, demonstrating that WSSV is not closely related to this virus group (Nadala et al. 1998; van Hulten, Goldbach \& Vlak 2000b; Chen et al. 2002a,b; Huang et al. 2002a,b; van Hulten et al. 2002; Tsai et al. 2004; Zhan, Wang, Chen, Xing \& Fukuda 2004; Zhang et al. 2004; Huang, Xie, Zhang \& Shi 2005; Leu et al. 2005; Marks 2005; Xie \& Yang 2005; Zhu et al. 2005). As WSSV is a distinct new virus, it has been (C) 2008 The Authors. Journal compilation (C) 2008 Blackwell Publishing Ltd assigned to its own virus family Nimaviridae (van
Hulten \& Vlak 2001, 2002; Vlak, Bonami, Flegel, Kou, Lightner, Lo, Loh \& Walker 2005).

\section{Genetic, antigenic and virulence variability in WSSV strains}

The genome of three WSSV isolates has been fully sequenced: Thailand $293 \mathrm{kbp}$ (van Hulten et al. 2001b), China $305 \mathrm{kbp}$ (Yang et al. 2001) and Taiwan $307 \mathrm{kbp}$ (Chen et al. 2002a). The nucleotide identity between these isolates is $99.3 \%$ (Marks 2005).

In silico restriction analysis with the enzyme $K p n \mathrm{I}$ predicts 27 fragments for the Chinese and Taiwanese isolates and 25 for the Thai isolate (Fig. 3). Nine fragments of $0.3,0.5,0.7,4.2,4.7,5.3,5.4$, 8.3 and $10.8 \mathrm{kbp}$ are identical in size for all three isolates. Two fragments of approximate sizes of 9 and $20 \mathrm{kbp}$, respectively, are missing in the Thai isolate. The remaining 14-16 fragments vary in size from 1.2 to $18 \mathrm{kbp}$ between the isolates.

Experimental restriction analysis with HindIII in several WSSV isolates also found differences in restriction fragment length polymorphism (RFLP) between a Chinese isolate (F. chinensis), two isolates from Indonesia ( $P$. monodon) and one from the USA (Farfantepenaeus setiferus). The latter two isolates were more similar to each other (Nadala \& Loh 1998).

Other WSSV isolates from China ( $F$. chinensis), India ( $P$. monodon), Thailand ( $P$. monodon and $L$. vannamei) and the USA (crayfish, Orconectes punctimanus from Washington and L. vannamei from South Carolina and Texas) were compared by dot blot hybridization using a DNA probe from a Taiwanese isolate. With this method, negative results or a very faint signal were found in some samples from India, Thailand and Texas. This finding suggests important differences between these isolates. Further RFLP analysis of PCR products from 10 different primer sets showed that the Texas isolate was very different from the others (Lo, Hsu, Tsai, Ho, Peng, Kou \& Lightner 1999).

Different regions of the WSSV genome display important sequence variations which can be used to establish the origin of a WSSV isolate and its spread within a certain area (Dieu, Marks, Siebenga, Goldbach, Zuidema, Duong \& Vlak 2004; Hoa, Hodgson, Oanh, Phuong, Preston \& Walker 2005) and also to differentiate isolates in the field (Wongteerasupaya, Pungchai, Withyachumnarnkul, Boonsaeng, Panyim, Flegel \& Walker 2003; Marks 
2005). Such variability may also induce falsenegative results when using certain PCR primers (Claydon et al. 2004; Kiatpathomchai, Taweetungtragoon, Jittivadhana, Wongteerasupaya, Boonsaeng \& Flegel 2005). An unstable region of $9.6 \mathrm{kbp}$ of the Chinese WSSV genome appears to undergo spontaneous deletions of different sizes depending on the host species. This observation has led to the suggestion that such deletions may play an important function in WSSV virulence (Lan, Lu $\& \mathrm{Xu} 2002)$.

The protein profiles of the six WSSV isolates described in Lo et al. (1999) and isolates from India and Korea were very similar as all of them displayed at least three major structural proteins (VP28, VP24 and VP19). An additional band corresponding to VP15 was found in four isolates. The sequence of the amino-terminal portion of these proteins was identical between isolates (Wang, Poulos \& Lightner 2000; Rajendran, Mukherjee, Vijayan, Jung, Kim \& Oh 2004).

Several WSSV isolates from the USA ( $F$. setiferus and $L$. vannamei), Panama, China (F. chinensis and $M$. japonicus), Indonesia ( $P$. monodon), Japan (M. japonicus), Thailand, Malaysia, Taiwan or different isolates from India were shown to have low antigenic variability using polyclonal or monoclonal antibodies (from whole WSSV virions or raised against full or truncated recombinants of VP28) in different immunoassays such as immunodot assays (Nadala \& Loh 2000; You, Nadala, Yang, van Hulten \& Loh 2002), Western blot (Shih, Wang, Tan \& Chen 2001; Yoganandhan, Syed Musthaq, Narayanan \& Sahul Hameed 2004), indirect immunofluorescence (IIF) (Poulos, Pantoja, Bradley-Dunlop, Aguilar \& Lightner 2001),

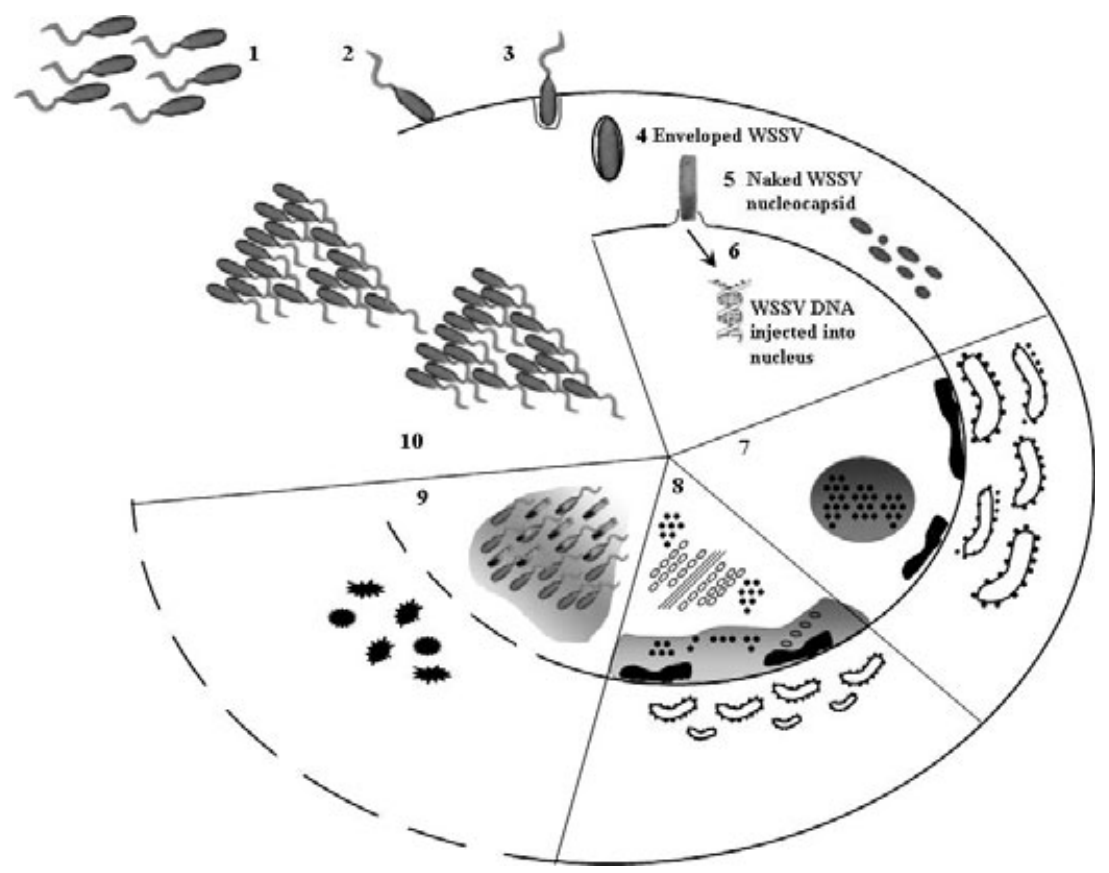

Figure 4 A proposed model of the morphogenesis of white spot syndrome virus (WSSV). (1) Infectious WSSV particles. (2) An infectious WSSV virion attaches to a susceptible cell using envelope proteins with a cell attachment motif. (3) WSSV enters the cell. (4) The envelope of the WSSV virion probably fuses with the endosome and the naked nucleocapsid is transported to the nucleus, in a similar way as in baculoviruses (see Lua \& Reid 2000). (5) The naked WSSV nucleocapsid attaches to the nuclear membrane and the WSSV genome is released into the nucleus. (6) The WSSV genome replication starts. In the cytoplasm, the mitochondria start degenerating (Wang et al. 1999a). (7) In the nucleus the early virogenic stroma appears composed of loose granular material. Cellular chromatin accumulates near the nuclear membrane and the rough endoplasmic reticulum (RER) becomes enlarged and active. (8) The marginated chromatin is transformed in a dense ring zone (shaded area). The virogenic stroma is less dense and starts forming vesicles that will form the viral envelope. The vesicles are probably formed with membranous material found in the ring zone, as in baculoviruses (see Lua \& Reid 2000). A viral nucleosome is also observed as a filamentous structure in the virogenic stroma. This structure contains proteins that will form the nucleocapsid. (9) New WSSV particles are assembled in the nucleus within an electron-dense inclusion. The empty envelopes are filled with a nucleocapsid. In cytoplasm, organelles become disintegrated and the cellular and nuclear membranes are disrupted (Wang et al. 1999a). (10) WSSV virions are completely formed and ready to be released from the disrupted cell to begin

(C) 2008 The Authors. Journal compilation (c) 2008 Blackwell Publishing Ltd 
immunohistochemistry (IHC) (Anil, Shankar \& Mohan 2002) or enzyme-linked immunosorbent assay (Zhang, Xu \& Xu 2001).

Differences in virulence of six WSSV isolates were found in post-larvae of L. vannamei and juveniles of $F$. duorarum inoculated per os. Virulence was determined as the time required to induce $100 \%$ mortality in L. vannamei. The Texas isolate was the most virulent while the Washington isolate (from crayfish) was the least virulent. The shrimp F. duorarum is known to be more resistant to WSSV infection. In this species, cumulative mortality was $60 \%$ with the Texas isolate and $35 \%$ with the WSSV isolate from crayfish (Wang et al. 1999b). Another study showed that differences in virulence and competitive fitness may be dependent on the genome size. A putative ancestral WSSV isolate (WSSV-TH96-II) with the largest genome size recorded (312 kbp), showed a lower virulence [median lethal time $\left(\mathrm{LT}_{50}\right)=14$ days] and competitive fitness compared with another WSSV isolate (WSSV-TH) with a smaller genome size (292 kbp) $\left(\mathrm{LT}_{50}=3.5\right.$ days $)$. This study indicated that WSSV isolates with a smaller genome size may represent an advantage for virus replication (Marks 2005).

\section{Morphogenesis}

The stages of WSSV morphogenesis have been characterized and are directly related to the development of cellular lesions (Durand et al. 1997; Wang, Hassan, Shariff, Zamri \& Chen 1999a; Tsai, Wang, Leu, Wang, Zhuang, Walker, Kou \& Lo 2006) (see Fig. 4).

Stage 1: the early stage of cell infection. Infected cells show slightly hypertrophied nuclei. A viral nucleosome appears before the formation of viral particles. It is composed of viral proteins organized in fibrillar fragments. In the cytoplasm, the endoplasmatic reticulum (ER) becomes enlarged with abundant free ribosomes.

Stage 2: in the nucleus, the fibrillar material induces the formation of circular membranes that are soon filled with viral core material starting viral assembly. At this stage, Cowdry-A type inclusions appear as a translucent zone between the virogenic stroma and the very electron-dense marginated chromatin. The nuclei become hypertrophied and rounded.

Stage 3: in the nucleus, the nucleocapsids appear with low electron density and gradually grow from intranuclear inclusion appears smaller than in cells in stage 2 and is more electron dense because of the presence of abundant viral particles. When the marginated chromatin disappears, the nuclear membrane is disrupted and the marginal transparent zone is fused with the lucent cytoplasm. Most organelles are abnormal, disintegrated or forming membranous structures.

Stage 4: in the nucleus, the nucleocapsid is completed with 12-14 rings of globular protein units arranged in a stacked series. Each nucleocapsid has one round and one square end. The nucleocapsid becomes completely enclosed by the envelope.

Stage 5: a late stage of viral morphogenesis. The viral particles become ovoid in shape and a long tail-like projection derived from the envelope is observed. The inner material of the tail is separated from the nucleocapsid. Afterwards, the nucleocapsids become shorter, thicker and more electron dense because of the packing of the viral DNA-VP15 complex.

Stage 6: the final phase of morphogenesis. The mature virions are elliptical with complete smooth envelopes enclosing an electron-dense nucleocapsid and with a tail-like projection at the last enclosed end. Sometimes assembly of nucleocapsids occurs completely separated from the envelopes and later they are wrapped by the envelopes. At this final stage, infected cells are severely damaged and disrupted. Void spaces are observed in tissues as cells disintegrate.

\section{Clinical signs and pathology}

Under culture conditions, many Asian and American penaeid species infected with WSSV display obvious white spots or patches of $0.5-3.0 \mathrm{~mm}$ in diameter embedded in the exoskeleton (Lo, Leu, Ho, Chen, Peng, Chen, Chou, Yeh, Huang, Chou, Wang \& Kou 1996a; Kasornchandra et al. 1998; Wu, Namikoshi, Nishizawa, Mushiake, Teruya \& Muroga 2001; T.W. Flegel, pers. comm.) (Fig. 5). The exact mechanism of white spot formation is not known. It is possible that a WSSV infection may induce the dysfunction of the integument resulting in the accumulation of calcium salts within the cuticle and giving rise to white spots (Wang et al. 1999a). Other signs of disease include a reddish discolouration of body and appendages because of the expansion of chromatophores (Lightner, Hasson, White \& Redman 1998; Nadala et al.1998), a 


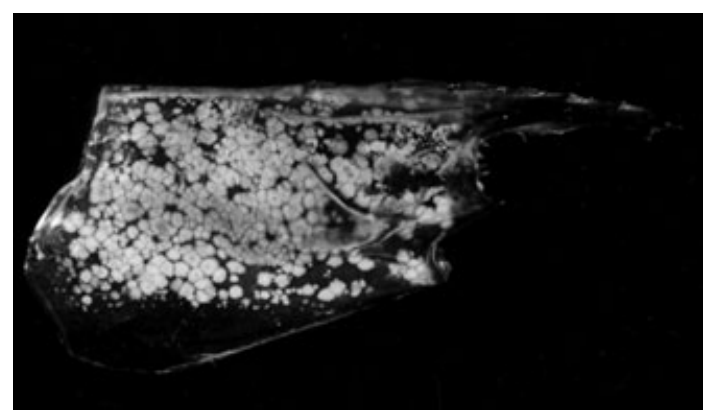

Figure 5 Presence of white spots in the carapace of farmed Penaeus monodon infected with white spot syndrome virus.

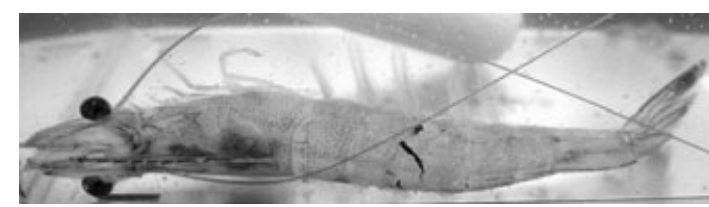

Figure 6 Experimentally white spot syndrome virus-infected moribund Litopenaeus vannamei with empty gut.

reduction in feed uptake (Chou et al. 1995; Durand et al. 1996; Flegel 1997), preening and response to stimulus (Wongteerasupaya et al. 1995; Durand et al. 1997) (Fig. 6), loose cuticle (Lo, Ho, Peng, Chen, Hsu, Chiu, Chang, Liu, Su, Wang \& Kou 1996b), swelling of branchiostegites because of accumulation of fluid (Otta, Shubha, Joseph, Chakraborty, Karunasagar \& Karunasagar 1999), enlargement and yellowish discolouration of the hepatopancreas (Sahul-Hameed et al. 1998), and thinning and delayed clotting of haemolymph (Wang et al. 2000; Kiatpathomchai, Boonsaeng, Tassanakajon, Wongteerasupaya, Jitrapakdee \& Panyim 2001).

In the field, WSSV-infected shrimp gather near the pond edge and display clinical signs 1 or 2 days before the first mortalities occur (Kou, Peng, Chiu $\&$ Lo 1998). Cumulative mortality may reach $100 \%$ within 10 days after the onset of disease (Karunasagar et al. 1997; Lotz \& Soto 2002). In grow-out ponds, juvenile shrimp of all ages and sizes are susceptible to the disease but massive mortality usually occurs 1 or 2 months after stocking (Kasornchandra et al. 1998).

By histopathology, WSSV infection is characterized by cells with hypertrophied nuclei showing amphophilic intranuclear inclusions and marginated chromatin (Durand et al. 1997; Wang et al. 2000) (Fig. 7). These intranuclear inclusions are

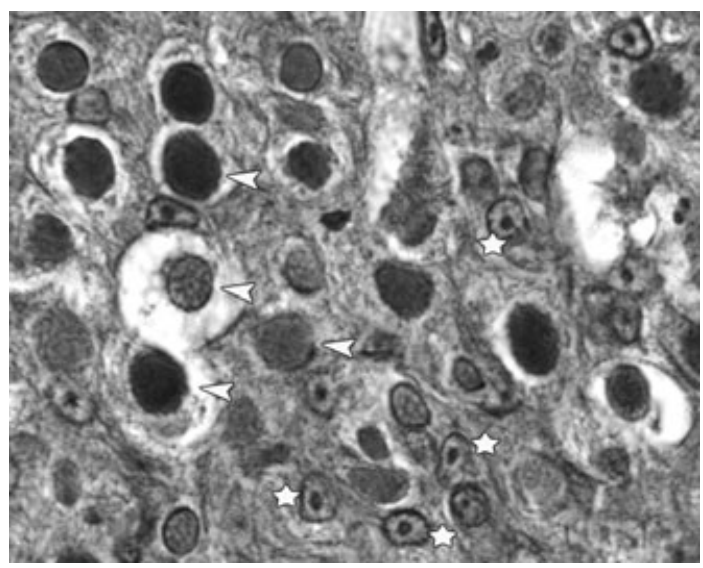

Figure 7 Histopathological lesions of white spot syndrome virus (WSSV) infection in cells of stomach. Stars indicate cells at early stages of WSSV replication containing Cowdry-A type-like intranuclear inclusions. Arrowheads indicate cells at late stages of WSSV replication showing hypertrophied nuclei with amphophilic intranuclear inclusions $(\times 1000)$.

markedly distinct and bigger than the Cowdry A-type inclusions characteristic of the infectious hypodermal and haematopoietic necrosis virus (Wongteerasupaya et al. 1995). Infected nuclei become progressively more basophilic and enlarged (Chang et al. 1996; Durand et al. 1996, 1997; Lo et al. 1996b; Flegel 1997; Wang, Lo, Chang \& Kou 1998a; Otta et al. 1999; Takahashi, Kondo, Itami, Honda, Inagawa, Nishizawa, Soma \& Yokomiso 2000). In the late stages of infection, karyorrhexis and cellular disintegration may occur, leading to the formation of necrotic areas characterized by vacuolization (Karunasagar et al. 1997; Kasornchandra et al. 1998; Wang et al. 1999a).

\section{Pathogenesis}

Experimental methods of WSSV inoculation that simulate natural routes of virus entry have been developed. These inoculation methods are: (i) waterborne, by immersing animals in water containing WSSV cell-free suspensions (Chou, Huang, Lo \& Kou 1998; Supamattaya, Hoffman, Boonyaratpalin \& Kanchanaphum 1998) and (ii) feeding WSSV-infected tissues to the animals for a single time or once daily for up to 7 days (Chang, Chen \& Wang 1998; Lightner et al. 1998; Wang, Tsai \& Chen 1998b; Rajan, Ramasamy, Purushothaman \& Brennan 2000). The latter route is considered the most important in natural and culture conditions 
Table 3 White spot syndrome virus host range

\begin{tabular}{|c|c|c|c|c|c|}
\hline \multirow[b]{2}{*}{ Animal } & \multirow[b]{2}{*}{ Species } & \multicolumn{2}{|c|}{ Type of infection } & \multirow[b]{2}{*}{ Detection method } & \multirow[b]{2}{*}{ Country (references) } \\
\hline & & Natural & Experimental & & \\
\hline \multirow{18}{*}{$\begin{array}{l}\text { Penaeid } \\
\text { shrimp }\end{array}$} & Farfantepenaeus aztecus & & $x$ & Histopathology & USA $^{10}$ \\
\hline & F. duorarum & & $x$ & Histopathology & USA $^{10}$ \\
\hline & Fenneropenaeus chinensis & $x$ & $x$ & Histopathology, ISH, PCR & China, Korea, Thailand ${ }^{13}, 25,26$ \\
\hline & F. indicus & $x$ & $x$ & Histopathology, PCR, TEM & India, Indonesia, Thailand ${ }^{14,} 15$ \\
\hline & F. merguiensis & $x$ & $x$ & Histopathology, PCR, IIF & Malaysia, Thailand ${ }^{3}, 4,18,19$ \\
\hline & Litopenaeus setiferus & & $x$ & Histopathology & USA $^{10}$ \\
\hline & L. stylirostris & $x$ & $x$ & Histopathology & USA, Latin America ${ }^{10,13}$ \\
\hline & L. vannamei & $x$ & $x$ & Histopathology, ISH, TEM & USA, Latin America ${ }^{10,13}$ \\
\hline & Marsupenaeus japonicus & $x$ & $x$ & Histopathology, PCR, TEM & China, Japan, India ${ }^{11,} 13,23,24,26$ \\
\hline & Metapenaeus dobsonii & $x$ & $x$ & Histopathology, PCR, TEM & India ${ }^{4,16}$ \\
\hline & M. ensis & $x$ & $x$ & ISH, PCR & Taiwan $^{1,11,23,24}$ \\
\hline & M. monoceros & & $x$ & PCR & India ${ }^{16}$ \\
\hline & Penaeus monodon & $x$ & $x$ & Histopathology, ISH, PCR & $\begin{array}{l}\text { At least eight Asian } \\
\text { countries }^{1,11}, 14,15,23,24,26\end{array}$ \\
\hline & P.penicillatus & $x$ & & ISH, PCR & Taiwan $^{11,23}$ \\
\hline & P. semisulcatus & $x$ & $x$ & ISH, PCR & India, Taiwan 11, 15, 23 \\
\hline & Parapenaeopsis stylifera & $x$ & & PCR & India $^{4}$ \\
\hline & Solenocera indica & $\mathrm{x}$ & & PCR & India ${ }^{4}$ \\
\hline & Trachypenaeus curvirostris & $x$ & $x$ & ISH, PCR & Taiwan²3, 24 \\
\hline \multirow{8}{*}{$\begin{array}{l}\text { Caridean } \\
\text { shrimp }\end{array}$} & Alpheus sp. & & $x$ & PCR & Thailand $^{11}$ \\
\hline & Callianassa sp. & & $x$ & PCR & Thailand $^{11}$ \\
\hline & Exopalaemon orientalis & & $x$ & ISH, PCR & Taiwan²3, 24 \\
\hline & Palaemon sp. & $x$ & & ISH, PCR & Taiwan $^{11}$ \\
\hline & P. adspersus & & $\mathrm{x}$ & TEM, ISH, PCR, dot-blot & France $^{2}$ \\
\hline & Macrobrachium idella & & $x$ & Histopathology, WB & India ${ }^{5}$ \\
\hline & M. lamerrae & & $x$ & Histopathology, WB & India $^{17}$ \\
\hline & M. rosenbergii & $x$ & $x$ & Histopathology, ISH, PCR & India, Taiwan ${ }^{4}, 11,15,23,24$ \\
\hline \multirow[t]{7}{*}{ Lobster } & Panulirus homarus & & $x$ & Histopathology & India ${ }^{15}$ \\
\hline & P. longipes & $x$ & $x$ & ISH, PCR & Taiwan $^{24}$ \\
\hline & $P$. ornatus & $x$ & $x$ & Histopathology, ISH, PCR & India, Taiwan 15, 23 \\
\hline & P. penicillatus & & $x$ & ISH, PCR & India, Taiwan ${ }^{1,23}$ \\
\hline & P. polyphagus & $x$ & $x$ & Histopathology & India ${ }^{15}$ \\
\hline & P. versicolor & $x$ & $x$ & ISH, PCR & Taiwan $^{1,23}$ \\
\hline & Scyllarus arctus & & $x$ & TEM, ISH, PCR, Dot-blot & France $^{2}$ \\
\hline \multirow[t]{7}{*}{ Crayfish } & Astacus astacus & & $x$ & PCR & Sweden $^{7}$ \\
\hline & A. leptodactylus & & $x$ & TEM, ISH, PCR, Dot-blot & France $^{2}$ \\
\hline & Cherax destructor & & $x$ & Histopathology, Dot-blot & Australia $^{3}$ \\
\hline & C. quadricarinatus & & $x$ & Histopathology, ISH, TEM & China $^{20}$ \\
\hline & Pacifastacus leniusculus & & $x$ & Histopathology, ISH & Sweden ${ }^{6}$ \\
\hline & Procambarus clarkii & & $x$ & ISH, PCR & China, Taiwan $1,5,23$ \\
\hline & Orconectes limosus & & $x$ & TEM, ISH, PCR, Dot-blot & France $^{2}$ \\
\hline \multirow[t]{21}{*}{ Crab } & Atergatis integerrimus & & $x$ & PCR & India ${ }^{19}$ \\
\hline & Calappa philarigus & $x$ & $x$ & Histopathology, ISH, PCR & India, Taiwan9, 19 \\
\hline & Callinectes lophos & & $x$ & ISH, PCR & Taiwan $^{23}$ \\
\hline & Cancer pagurus & & $x$ & TEM, ISH, PCR, Dot-blot & France $^{2}$ \\
\hline & Carcinus maenas & & $x$ & TEM, ISH, PCR, Dot-blot & France $^{2}$ \\
\hline & Charybdis annulata & $x$ & $x$ & Histopathology, PCR & India 4,19 \\
\hline & C. cruciata & & $x$ & PCR & India ${ }^{4}$ \\
\hline & C.feriatus & $x$ & $x$ & Histopathology, ISH, PCR & India, Taiwan 9, 11, 23 \\
\hline & C. granulata & & $x$ & $\mathrm{ISH}$ & Taiwan $^{1,23}$ \\
\hline & C. lucifera & $x$ & $x$ & Histopathology, PCR & India $^{12,19}$ \\
\hline & C. natatus & $x$ & $x$ & Histopathology, ISH PCR & India, Taiwan, Thailand ${ }^{9,} 19$ \\
\hline & Demania splendida & & $x$ & PCR & India ${ }^{19}$ \\
\hline & Doclea hybrida & & $x$ & Histopathology, PCR & India ${ }^{19}$ \\
\hline & Gelasimus marionis nitidus & $x$ & & PCR & India ${ }^{4}$ \\
\hline & Grapsus albolineatus & & $x$ & Histopathology, PCR & India ${ }^{19}$ \\
\hline & Halimede ochtodes & & $x$ & Histopathology, PCR & India ${ }^{19}$ \\
\hline & Helice tridens & $x$ & & PCR & Taiwan, Thailand $^{9,11}$ \\
\hline & Liagore rubronaculata & & $x$ & Histopathology, PCR & India ${ }^{19}$ \\
\hline & Liocarcinus depurator & & $x$ & TEM, ISH, PCR, Dot-blot & France,India 8,15 \\
\hline & L. puber & & $x$ & TEM, ISH, PCR, Dot-blot & France, India ${ }^{8,15}$ \\
\hline & Lithodes maja & & $x$ & Histopathology, PCR & India ${ }^{19}$ \\
\hline
\end{tabular}


Table 3 (Continued)

\begin{tabular}{|c|c|c|c|c|c|}
\hline \multirow[b]{2}{*}{ Animal } & \multirow[b]{2}{*}{ Species } & \multicolumn{2}{|c|}{ Type of infection } & \multirow[b]{2}{*}{ Detection method } & \multirow[b]{2}{*}{ Country (references) } \\
\hline & & Natural & Experimental & & \\
\hline \multirow[t]{20}{*}{ Crab } & Macrophthalmus sulcatus & $x$ & & PCR & India ${ }^{4}$ \\
\hline & Matuta miersi & & $x$ & Histopathology, PCR & India ${ }^{19}$ \\
\hline & M. planipes & $x$ & & PCR & India $^{12}$ \\
\hline & Menippe rumphii & & $x$ & PCR & India ${ }^{19}$ \\
\hline & Metapograpsus sp. & & $x$ & Histopathology & India, Taiwan ${ }^{15}$ \\
\hline & Metapograpsus messor & $x$ & & PCR & India $^{4}$ \\
\hline & Paradorippe granulata & & $x$ & Histopathology, PCR & India $^{19}$ \\
\hline & Paratelphusa hydrodomous & & $x$ & Histopathology, PCR, & India $^{18}$ \\
\hline & P. pulvinata & & $x$ & Histopathology, PCR, & India $^{18}$ \\
\hline & Parthenope prensor & & $x$ & Histopathology, PCR & India ${ }^{19}$ \\
\hline & Phylira syndactyla & & $x$ & Histopathology, PCR & India ${ }^{19}$ \\
\hline & Podophthalmus vigil & & $x$ & Histopathology, PCR & India $^{19}$ \\
\hline & Portunus pelagicus & $x$ & $x$ & Histopathology, ISH, TEM & Taiwan, Thailand ${ }^{9,11,21}$ \\
\hline & P. sanguinolentus & $x$ & $x$ & Histopathology, ISH, PCR & India, Taiwan ${ }^{1,9}, 11,19,24$ \\
\hline & Sesarma sp. & & $x$ & Histopathology, ISH, PCR & India, Thailand ${ }^{8,15}$ \\
\hline & S. oceanica & $\mathrm{x}$ & & PCR & India ${ }^{12}$ \\
\hline & Scylla serrata & $x$ & $x$ & Histopathology, ISH, PCR & $\begin{array}{l}\text { India, Taiwan, } \\
\text { Thailand }^{8,9}, 11,15,19,21\end{array}$ \\
\hline & S. tranquebaricca & & $x$ & Histopathology & India ${ }^{15}$ \\
\hline & Thalamite danae & & $x$ & Histopathology, PCR & India ${ }^{19}$ \\
\hline & Uca pugilator & & $x$ & Histopathology, ISH & Thailand $^{8}$ \\
\hline \multirow[t]{10}{*}{ Other } & Sergestoidea, Acetes sp. & $x$ & $x$ & Histopathology, ISH, PCR & Thailand ${ }^{21}$ \\
\hline & Cirripedia Balanus sp. & $\mathrm{x}$ & $x$ & PCR & Mexico, Thailand ${ }^{11,} 16$ \\
\hline & Branchiopoda Cladocera & $\hat{x}$ & & PCR & Mexico $^{16}$ \\
\hline & Branchiopoda Artemia sp. & $x$ & & PCR & India ${ }^{12}$ \\
\hline & Stomatopoda, Squilla mantis & $\hat{x}$ & & PCR & India ${ }^{4}$ \\
\hline & Copepoda & $x$ & & PCR & Mexico, Thailand ${ }^{11,} 16$ \\
\hline & Chaetognata & $x$ & & PCR & Mexico $^{16}$ \\
\hline & Rotifera & $x$ & & PCR & China $^{25}$ \\
\hline & Polychaeta, Marphysa sp. & $x$ & & PCR & India 22 \\
\hline & Coleoptera Ephydridae & $x$ & & PCR & Taiwan $^{11}$ \\
\hline
\end{tabular}

References: ${ }^{1}$ Chang et al. 1998; ${ }^{2}$ Corbel et al. 2001; ${ }^{3}$ Edgerton 2004; ${ }^{4}$ Hossain et al. 2001; ${ }^{5}$ Huang et al. 2001; ${ }^{6}$ Jiravanichpaisal et al. 2001, 2004; ${ }^{8}$ Kanchanaphum et al. 1998; ${ }^{9}$ Kou et al. 1998; ${ }^{10}$ Lightner et al. $1998 ;{ }^{11}$ Lo et al. 1996b; ${ }^{12}$ Lo et al. 1999; ${ }^{13}$ Lu et al. $1997 ;{ }^{14}$ Rajan et al. 2000 ;

${ }^{15}$ Rajendran et al. 1999; ${ }^{16}$ Ramírez-Douriet et al. 2005; ${ }^{17}$ Sahul-Hameed et al. 2000; ${ }^{18}$ Sahul-Hameed et al. 2001; ${ }^{19}$ Sahul-Hameed et al. 2003; ${ }^{20}$ Shi et al. 2000; ${ }^{21}$ Supamattaya et al. 1998; ${ }^{22}$ Vijayan et al. 2005; ${ }^{23}$ Wang et al. 1998a; ${ }^{24}$ Wang et al. 1998b; ${ }^{25}$ Yan et al. 2004; ${ }^{26} \mathrm{Zhan}$ et al. 1998;

PCR, polymerase chain reaction; ISH, in situ hybridization; TEM, transmission electron microscopy; IIF, indirect immunofluorescence.

(Chou et al. 1998; Wu et al. 2001; Lotz \& Soto 2002; Pramod-Kiran, Rajendran, Jung \& Oh 2002).

The portals of WSSV entry into the shrimp have not yet been clearly identified. According to experimental data on feeding shrimp with WSSV-infected tissues, the primary sites of WSSV replication in early juvenile $P$. monodon are the subcuticular epithelial cells of the stomach and cells in the gills, in the integument and in connective tissue of the hepatopancreas as determined by in situ hybridization (ISH) (Chang et al. 1996). Another study on M. japonicus indicated that epithelial cells in the midgut trunk may be a transient site of WSSV replication which would allow the virus to cross the underlying basal lamina (Di Leonardo, Bonnichon, Roch, Parrinello \& Bonami 2005). In P. monodon, a WSSV challenge (C) 2008 The Authors. Journal compilation (C) 2008 Blackwell Publishing Ltd by immersion showed that haemocytes migrating to gills and midgut were WSSV-negative at late stages of infection [48-72 h post-inoculation (hpi)]. Many WSSV-positive cells were found in gills and only a few in midgut epithelium. Electron microscopy showed that epithelial cells in the midgut were VP28-positive in supranuclear vacuoles early during infection (8 hpi), suggesting lysis of WSSV particles. VP28-positive nuclei were never seen in the epithelial cells of the midgut (Arts, Taverne-Thiele, Savelkoul \& Rombout 2007).

Recently, the infectivity titres of a WSSV stock solution was determined by oral route challenge (Escobedo-Bonilla, Wille, Alday-Sanz, Sorgeloos, Pensaert \& Nauwynck 2005) and a standardized oral inoculation procedure that delivered an exact amount of virus titre to all inoculated shrimp was developed (Escobedo-Bonilla, Wille, Alday-Sanz, Sorgeloos, Pensaert \& Nauwynck 2006). With this standardized inoculation technique, the primary 
sites of WSSV replication as determined with IHC were the epithelial cells in the foregut, cells in the gills, and only with a high dose (10 000 SID $\left._{50}\right)$, also cells in the antennal gland (Escobedo-Bonilla, Wille, Alday-Sanz, Sorgeloos, Pensaert \& Nauwynck 2007).

The mechanism of viral spread from the primary replication sites to other target organs has been controversial. Some studies have indicated that WSSV infects haemocytes in crayfish and travels throughout the body in these cells to reach distant target organs (Wang, Liu, Seah, Lam, Xiang, Korzh \& Kwang 2002; Di Leonardo et al. 2005). Other studies have shown by ISH, IHC and IIF that circulating haemocytes in freshwater prawns and shrimp are refractory to WSSV infection (van De Braak, Botterblom, Huisman, Rombout \& van der Knaap 2002; Shi, Wang, Zhang, Xie, Li, Chen, Edgerton \& Bonami 2005; Escobedo-Bonilla et al. 2007), thus indicating that WSSV might reach other target organs through haemolymph circulation in a cell-free form (Escobedo-Bonilla et al. 2007). It is possible that these mechanisms of spread may be host species-dependent.

White spot syndrome virus targets cells of organs of ectodermal and mesodermal origin, including those of the epidermis, gills, foregut, hindgut (Wongteerasupaya et al. 1995; Chang et al. 1996), antennal gland, lymphoid organ (Durand et al. 1996; Chang et al. 1998), muscle, eye-stalk, heart (Kou et al. 1998), gonads (Lo, Ho, Chen, Liu, Chiu, Yeh, Peng, Hsu, Liu, Chang, Su, Wang \& Kou 1997), haematopoietic cells and cells associated with the nervous system (Rajendran et al. 1999; Wang et al. 1999b). Epithelial cells of organs of endodermal origin such as the hepatopancreas, anterior and posterior midgut caeca and midgut trunk are refractory to WSSV infection (SahulHameed et al. 1998). In the late stages of infection, the epithelia of the stomach, gills and integument may become severely damaged (Chang et al. 1996; Wang et al. 1999a). This may cause multiple organ dysfunctions and probably leads to death.

A number of techniques such as two-dimensional gel electrophoresis, expressed sequence tags (Wang, Wang, Leu, Kou, Wang \& Lo 2007), microarray chips (Wang, Li, Dong, Zhang, Zhang \& Xiang 2006), suppression subtractive hybridization (Zhao, Yin, Weng, Guan, Li, Xing, Chan \& He 2007) and differential hybridization (He, Qin \& Xu 2005) are useful tools to better understand the host response esis. These methods measure the altered abundance of host and/or viral mRNA and/or protein expression levels after WSSV infection. Molecules with important biological functions that showed variations in response to WSSV infection included those involved in energy production, nucleic acid synthesis, calcium homeostasis and/or cellular signalling. Many such molecules may be useful as biomarkers and probably could be used to identify targets to control virus replication (Wang et al. 2007).

\section{Host range}

White spot syndrome virus has a broad host range within decapod crustaceans. At least 18 cultured and/or wild penaeid shrimp (Wongteerasupaya, Wongwisansri, Boonsaeng, Panyim, Pratanpipat, Nash, Withyachumnarnkul \& Flegel 1996; Durand et al. 1997; Lu, Tapay, Loh, Gose \& Brock 1997; Chou et al. 1998; Lightner et al. 1998; Park et al. 1998), eight caridean species (Sahul-Hameed, Charles \& Anilkumar 2000; Shi, Huang, Zhang, Chen \& Bonami 2000; Pramod-Kiran et al. 2002), seven species of lobster (Chang et al. 1998; Rajendran et al. 1999), seven species of crayfish (Wang et al. 1998a; Corbel, Zuprisal, Shi, Huang, Sumartono, Arcier \& Bonami 2001; Jiravanichpaisal, Bangyeekhun, Söderhäll \& Söderhäll 2001; Edgerton 2004; Jiravanichpaisal, Soderhall \& Soderhall 2004), 38 crab species (Lo et al. 1996a; Kanchanaphum, Wongteerasupaya, Sitidilokratana, Boonsaeng, Panyim, Tassanakajon, Withyachumnarnkul \& Flegel 1998; Kou et al. 1998; Sahul-Hameed, Yoganandhan, Sathish, Rasheed, Murugan \& Jayaraman 2001; Sahul-Hameed, Balasubramanian, Syed Musthaq \& Yoganandhan 2003), six non-decapod crustacean species (Supamattaya et al. 1998; Otta et al. 1999; Hossain, Chakraborty, Joseph, Otta, Karunasagar \& Karunasagar 2001), members of the phyla Chaetognata and Rotifera (Yan, Dong, Huang, Yu \& Feng 2004; Ramírez-Douriet, De Silva-Dávila, Méndez-Lozana, Escobedo-Urias, Leyva-Arana \& López-Meyer 2005; Yan, Dong, Huang \& Zhang 2007), polychaete worms (Supak, Boonnat, Poltana, Kanchanaphum, Gangnonngiw, Nash \& Withyachumnarnkul 2005; Vijayan, Stalin Raj, Balasubramanian, Alavandi, Thillai Sekhar \& Santiago 2005) and some aquatic insect larvae (Lo et al. 1996b; Flegel 1997; Ramírez-Douriet et al. 2005) have been found to be WSSV-positive by PCR (Table 3). Although many of these species have 
been confirmed to support WSSV replication under experimental conditions, some other species collected from the wild have only been found WSSVpositive by PCR. This indicates that many such species are not necessarily WSSV natural hosts, but may only be mechanical carriers. This seems to be the case at least for polychaete worms (T.W. Flegel, pers. comm.).

\section{Acknowledgements}

C.M.E.-B. received a scholarship (110056) from CONACyT (Mexico). This work was funded by a grant from the Belgian Ministry of Science Policy. Thanks to Professor T.W. Flegel for his useful comments on this paper.

\section{References}

Anil T.M., Shankar K.M. \& Mohan C.V. (2002) Monoclonal antibodies developed for sensitive detection and comparison of white spot syndrome virus isolates in India. Diseases of Aquatic Organisms 51, 67-75.

Anonymous (2003) Manual of Diagnostic Tests for Aquatic Animals. Office International des Epizooties, Paris, France.

APHIS-USDA (2005) Impact Worksheet White Spot Disease in Brazil. APHIS-USDA, Natural Resources Research: Fort Collins, CO Center.

Arts J.A.J., Taverne-Thiele A.J., Savelkoul H.F.J. \& Rombout J.H.W.M. (2007) Hemocyte reactions in WSSV immersion infected Penaeus monodon. Fish \& Shellfish Immunology 23, 164-170.

Bondad-Reantaso M.G., Mcgladdery S.E., East I. \& Subasinghe R.P. (2001) Asia Diagnostic Guide to Aquatic Animal Diseases. FAO, Rome, Italy.

Chang P.S., Lo C.F., Wang Y.C. \& Kou G.H. (1996) Identification of white spot syndrome virus associated baculovirus (WSBV) target organs in the shrimp Penaeus monodon by in situ hybridization. Diseases of Aquatic Organisms 27, 131139.

Chang P.S., Chen H.C. \& Wang Y.C. (1998) Detection of white spot syndrome associated baculovirus in experimentally infected wild shrimp, crabs and lobsters by in situ hybridization. Aquaculture 164, 233-242.

Chang C.F., Su M.S., Chen H.Y., Lo C.F., Kou G.H. \& Liao I.C. (1999) Effect of dietary $\beta$-1,3-glucan on resistance to white spot syndrome virus (WSSV) in postlarval and juvenile Penaeus monodon. Diseases of Aquatic Organisms 36, 163-168.

Chang C.F., Su M.S., Chen H.Y. \& Liao I.C. (2003) Dietary $\beta-1,3$-glucan effectively improves immunity and survival of Penaeus monodon challenged with white spot syndrome virus. Fish \& Shellfish Immunology 15, 297-310.

Chen L.L., Leu J.H., Huang C.J., Chou C.M., Chen S.M., Wang C.H., Lo C.F. \& Kou G.H. (2002a) Identification of a nucleocapsid protein (VP35) gene of shrimp white spot syn- drome virus and characterization of the motif important for targeting VP35 to the nuclei of transfected insect cells. Virology 293, 44-53.

Chen L.L., Wang H.C., Huang C.J., Peng S.E., Chen Y.G., Lin S.J., Chen W.Y., Dai C.F., Yu H.T. \& Wang C.H. (2002b) Transcriptional analysis of the DNA polymerase gene of shrimp white spot syndrome virus. Virology 301, 136-147.

Chou H.Y., Huang C.Y., Wang C.H., Chiang H.C. \& Lo C.F. (1995) Pathogenicity of a baculovirus infection causing white spot syndrome in cultured penaeid shrimp in Taiwan. Diseases of Aquatic Organisms 23, 165-173.

Chou H.Y., Huang C.Y., Lo C.F. \& Kou G.H. (1998) Studies on transmission of white spot syndrome associated baculovirus (WSBV) in Penaeus monodon and P. japonicus via waterborne contact and oral ingestion. Aquaculture 164, 263-276.

Claydon K., Cullen B. \& Owens L. (2004) OIE white spot syndrome virus PCR gives false-positive results in Cherax quadricarinatus. Diseases of Aquatic Organisms 62, 265-268.

Corbel V., Zuprisal Z., Shi Z., Huang C., Sumartono, Arcier J.M. \& Bonami J.R. (2001) Experimental infection of European crustaceans with white spot syndrome virus (WSSV). Journal of Fish Diseases 24, 377-382.

van De Braak C.B.T., Botterblom M.H.A., Huisman E.A., Rombout J.H.W.M. \& van der Knaap W.P.W. (2002) Preliminary study on the haemocyte response to white spot syndrome virus infection in black tiger shrimp Penaeus monodon. Diseases of Aquatic Organisms 51, 149-155.

Di Leonardo V.A., Bonnichon V., Roch P., Parrinello N. \& Bonami J.R. (2005) Comparative WSSV infection routes in the shrimp genera Marsupenaeus and Palaemon. Journal of Fish Diseases 28, 565-569.

Dieu B.T.M., Marks H., Siebenga J.J., Goldbach R.W., Zuidema D., Duong T.P. \& Vlak J.M. (2004) Molecular epidemiology of white spot syndrome virus within Vietnam. Journal of General Virology 85, 3607-3618.

Durand S., Lightner D.V., Nunan L.M., Redman R.M., Mari J. \& Bonami J.R. (1996) Application of gene probes as diagnostic tools for white spot baculovirus (WSBV) of penaeid shrimp. Diseases of Aquatic Organisms 27, 59-66.

Durand S., Lightner D.V., Redman R.M. \& Bonami J.R. (1997) Ultrastructure and morphogenesis of white spot syndrome baculovirus. Diseases of Aquatic Organisms 29, 205-211.

Durand S.V., Tang K.F.J. \& Lightner D.V. (2000) Frozen commodity shrimp: potential avenue for introduction of white spot syndrome virus and yellow head virus. Journal of Aquatic Animal Health 12, 128-135.

Edgerton B.F. (2004) Susceptibility of the Australian freshwater crayfish Cherax destructor albidus to white spot syndrome virus (WSSV). Diseases of Aquatic Organisms 59, 187-193.

Escobedo-Bonilla C.M., Wille M., Alday-Sanz V., Sorgeloos P., Pensaert M.B. \& Nauwynck H.J. (2005) In vivo titration of white spot syndrome virus (WSSV) in SPF Litopenaeus vannamei by intramuscular and oral routes. Diseases of Aquatic Organisms 66, 163-170.

Escobedo-Bonilla C.M., Wille M., Alday-Sanz V., Sorgeloos P., Pensaert M.B. \& Nauwynck H.J. (2006) Standardized white
(C) 2008 The Authors. Journal compilation (C) 2008 Blackwell Publishing Ltd 
spot syndrome virus (WSSV) inoculation procedures for intramuscular or oral routes. Diseases of Aquatic Organisms 68, 181-188.

Escobedo-Bonilla C.M., Wille M., Alday-Sanz V., Sorgeloos P., Pensaert M.B. \& Nauwynck H.J. (2007) Pathogenesis of a Thai strain of white spot syndrome virus (WSSV) in SPF Litopenaeu vannamei. Diseases of Aquatic Organisms 74, 85-94.

FAO (2006) Fishstat, Universal Software for Fishery Statistical Time Series, Version 2.3. FAO, Rome, Italy.

Flegel T.W. (1997) Special topic review: major viral diseases of the black tiger prawn (Penaeus monodon) in Thailand. World Journal of Microbiology \& Biotechnology 13, 433-442.

Flegel T.W. \& Alday-Sanz V. (1998) The crisis in Asian shrimp aquaculture: current status and future needs. Journal of Applied Ichthyology 14, 269-273.

Flegel T.W. \& Fegan D.F. (2002) Marine shipping could ballast water and hull fouling be a fomite for disease transmission? In: Proceedings of the Conference on World Aquaculture (ed. by The World Aquaculture Society), p. 226. The World Aquaculture Society, Beijing, China.

Han F. \& Zhang X. (2006) Internal initiation of mRNA translation in insect cell mediated by an internal ribosome entry site (IRES) from shrimp white spot syndrome virus (WSSV). Biochemical and Biophysical Research Communications 344, 893-899.

Han F., Xu J. \& Zhang X.. (2007) Characterization of an early gene (wsv477) from white spot syndrome virus (WSSV). Virus Genes 37, 193-198.

He N., Qin Q. \& Xu X. (2005) Differential profile of genes expressed in hemocytes of white spot syndrome virus-resistant shrimp (Penaeus japonicus) by combining suppression subtractive hybridization and differential hybridization. Antiviral Research 66, 39-45.

Hoa T.T.T., Hodgson R.A.J., Oanh D.T.H., Phuong N.T., Preston N.J. \& Walker P.J. (2005) Genotypic variations in tandem repeat DNA segments between ribonucleotide reductase subunit genes in WSSV isolates from Vietnam. In: Diseases in Asian Aquaculture V (ed. by P.J. Walker, R. Lester \& M.G. Bondad-Reantaso), pp. 339-352. Fish Health Section, Asian Fisheries Society, Manila, Philippines.

Hossain S., Chakraborty A., Joseph B., Otta S.K., Karunasagar I. \& Karunasagar I. (2001) Detection of new hosts for white spot syndrome virus of shrimp using nested polymerase chain reaction. Aquaculture 198, 1-11.

Huang C.H., Zhang L.R., Zhang J.H., Xiao L.C., Wu Q.J., Chen D.H. \& Li J.K.K. (2001) Purification and characterization of white spot syndrome virus (WSSV) produced in an alternate host: crayfish, Cambarus clarkii. Virus Research 76, $115-125$.

Huang C., Zhang X., Lin Q., Xu X., Hu Z. \& Hew C.L. (2002a) Proteomic analysis of shrimp white spot syndrome viral proteins and characterization of a novel envelope protein VP466. Molecular \& Cellular Proteomics 1, 223231.

Huang C., Zhang X., Lin Q., Xu X. \& Hew C.L. (2002b) Characterization of a novel envelope protein (VP281) of shrimp white spot syndrome virus by mass spectrometry.

(C) 2008 The Authors Journal of General Virology 83, 2385-2392.
Huang R., Xie Y., Zhang J. \& Shi Z. (2005) A novel envelope protein involved in white spot syndrome virus infection. Journal of General Virology 86, 1357-1361.

van Hulten M.C.W. \& Vlak J.M. (2001) Identification and phylogeny of a protein kinase gene of white spot syndrome virus. Virus Genes 22, 201-207.

van Hulten M.C.W. \& Vlak J.M. (2002) Genetic evidence for a unique taxonomic position of white spot syndrome virus of shrimp: genus Whispovirus. In: Diseases in Asian Aquaculture $I V$ (ed. by C.R. Lavilla-Pitogo \& E.R. Cruz-Lacierda), pp. 2535. Fish Health Section, Asian Fisheries Society, Cebu City, Philippines.

van Hulten M.C.W., Tsai M.F., Schipper C.A., Lo C.F., Kou G.H. \& Vlak J.M. (2000a) Analysis of a genomic segment of white spot syndrome virus of shrimp containing ribonucleotide reductase genes and repeat regions. Journal of General Virology 81, 307-316.

van Hulten M.C.W., Goldbach R.W. \& Vlak J.M. (2000b) Three functionally diverged major structural proteins of white spot syndrome virus evolved by gene duplication. Journal of General Virology 81, 2525-2529.

van Hulten M.C.W., Witteveldt J., Peters S., Kloosterboer N., Tarchini R., Fiers M., Sandbrink H., Klein-Langhorst R. \& Vlak J.M. (2001a) The white spot syndrome virus DNA genome sequence. Virology 286, 7-22.

van Hulten M.C.W., Witteveldt J., Snippe M. \& Vlak J.M. (2001b) White spot syndrome virus envelope protein VP28 is involved in the systemic infection of shrimp. Virology 285, 228-233.

van Hulten M.C.W., Reijns M., Vermeesch A.M.G., Zandbergen F. \& Vlak J.M. (2002) Identification of VP19 and VP15 of white spot syndrome virus (WSSV) and glycosylation status of the WSSV major structural proteins. Journal of General Virology, 83, 257-265.

Inouye K., Miwa S., Oseko N., Nakano H., Kimura T., Momoyama K. \& Hiraoka M. (1994) Mass mortalities of cultured kuruma shrimp, Penaeus japonicus, in Japan in 1993: electron microscopic evidence of the causative virus. Fish Pathology 29, 149-158.

Inouye K., Yamano K., Ikeda N., Kimura T., Nakano H., Momoyama K., Kobayashi J. \& Miyajima S. (1996) The penaeid rod-shaped DNA virus (PRDV), which causes penaeid acute viremia. Fish Pathology 31, 39-45.

Jiravanichpaisal P., Bangyeekhun E., Söderhäll K. \& Söderhäll I. (2001) Experimental infection of white spot syndrome virus in freshwater crayfish Pacifastacus leniusculus. Diseases of Aquatic Organisms 47, 151-157.

Jiravanichpaisal P., Soderhall K. \& Soderhall I. (2004) Effect of water temperature on the immune response and infectivity pattern of white spot syndrome virus (WSSV) in freshwater crayfish. Fish \& Shellfish Immunology 17, 265-275.

Kanchanaphum P., Wongteerasupaya C., Sitidilokratana N., Boonsaeng V., Panyim S., Tassanakajon A., Withyachumnarnkul B. \& Flegel T.W. (1998) Experimental transmission of white spot syndrome virus (WSSV) from crabs to shrimp Penaeus monodon. Diseases of Aquatic Organisms 34, 1-7.

Karunasagar I., Otta S.K. \& Karunasagar I. (1997) Histopathological and bacteriological study of white spot syndrome of

Journal compilation

(C) 2008

Blackwell Publishing Ltd 
Penaeus monodon along the west coast of India. Aquaculture 153, 9-13.

Kasornchandra J., Boonyaratpalin S. \& Itami T. (1998) Detection of white spot syndrome in cultured penaeid shrimp in Asia: microscopic observation and polymerase chain reaction. Aquaculture 164, 243-251.

Khadijah S., Neo Y.S., Hossain M.S., Miller L.D., Mathavan S. \& Kwang J. (2003) Identification of white spot syndrome virus latency-related genes in specific-pathogen-free shrimps by use of a microarray. Journal of Virology 77, 10162-10167.

Kiatpathomchai W., Boonsaeng V., Tassanakajon A., Wongteerasupaya C., Jitrapakdee S. \& Panyim S. (2001) A non-stop, single-tube, semi-nested PCR technique for grading the severity of white spot syndrome virus infections in Penaeus monodon. Diseases of Aquatic Organisms 47, 235-239.

Kiatpathomchai W., Taweetungtragoon A., Jittivadhana K., Wongteerasupaya C., Boonsaeng V. \& Flegel T.W. (2005) Target for standard Thai PCR assay identical in 12 white spot syndrome virus (WSSV) types that differ in DNA multiple repeat length. Journal of Virological Methods 130, 79-82.

Kim C.S., Kosuke Z., Nam Y.K., Kim S.K. \& Kim K.H. (2007) Protection of shrimp (Penaeus chinensis) against white spot syndrome virus (WSSV) challenge by double-stranded RNA. Fish \& Shellfish Immunology 23, 242-246.

Kou G.H., Peng S.E., Chiu Y.L. \& Lo C.F. (1998) Tissue distribution of white spot syndrome virus (WSSV) in shrimp and crabs. In: Advances in Shrimp Biotechnology (ed. by T.W. Flegel), pp. 267-271. National Center for Genetic Engineering and Biotechnology, Bangkok.

Lan Y., Lu W. \& Xu X. (2002) Genomic instability of prawn white spot bacilliform virus (WSBV) and its association to virus virulence. Virus Research 90, 264-274.

Leu J.H., Tsai J.M., Wang H.C., Wang A.H.J., Wang C.H., Kou G.H. \& Lo C.F. (2005) The unique stacked rings in the nucleocapsid of the white spot syndrome virus virion are formed by the major structural protein VP664, the largest viral structural protein ever found. Journal of Virology 79, $140-149$.

Li Q., Chen Y. \& Yang F. (2004) Identification of a collagen-like protein gene from white spot syndrome virus. Archives of Virology 149, 215-223.

Li L., Xie X. \& Yang F. (2005a) Identification and characterization of a prawn white spot syndrome virus gene that encodes an envelope protein VP31. Virology 340, 125-132.

Li L., Lin S. \& Yang F. (2005b) Functional identification of the non-specific nuclease from white spot syndrome virus. Virology 337, 399-406.

Li H., Zhu Y., Xie X. \& Yang F. (2006a) Identification of a novel envelope protein (VP187) gene from shrimp white spot syndrome virus. Virus Research 115, 76-84.

Li L.J., Yuan J.F., Cai C.A., Gu W.G. \& Shi Z.L. (2006b) Multiple envelope proteins are involved in white spot syndrome virus (WSSV) infection in crayfish. Archives of Virology 151, 1309-1317.

Lightner D.V. (1996) A Handbook of Pathology and Diagnostic Procedures for Diseases of Penaeid Shrimp. World Aquaculture Society, Baton Rouge, Louisiana, USA.
Lightner D.V., Hasson K.W., White B.L. \& Redman R.M. (1998) Experimental infection of western hemisphere penaeid shrimp with Asian white spot syndrome virus and Asian yellow head virus. Journal of Aquatic Animal Health 10, 271-281.

Liu X. \& Yang F. (2005) Identification and function of a shrimp white spot syndrome virus (WSSV) gene that encodes a dUTPase. Virus Research 110, 21-30.

Liu W.J., Chang Y.S., Wang C.H., Kou G.H. \& Lo C.F. (2005) Microarray and RT-PCR screening for white spot syndrome virus immediate-early genes in cycloheximide-treated shrimp. Virology 334, 327-341.

Liu Y., Wu J., Song J., Sivaraman J. \& Hew C.L. (2006) Identification of a novel nonstructural protein, VP9, from white spot syndrome virus: its structure reveals a ferredoxin fold with specific metal binding sites. Journal of Virology $\mathbf{8 0}$, 10419-10427.

Lo C.F., Leu J.H., Ho C.H., Chen C.H., Peng S.E., Chen Y.T., Chou C.M., Yeh P.Y., Huang C.J., Chou H.Y., Wang C.H. \& Kou G.H. (1996a) Detection of baculovirus associated with white spot syndrome (WSBV) in penaeid shrimp using polymerase chain reaction. Diseases of Aquatic Organisms 25, 133-141.

Lo C.F., Ho C.H., Peng S.E., Chen C.H., Hsu H.C., Chiu Y.L., Chang C.F., Liu K.F., Su M.S., Wang C.H. \& Kou G.H. (1996b) White spot syndrome baculovirus (WSBV) detected in cultured and captured shrimp, crabs and other arthropods. Diseases of Aquatic Organisms 27, 215-225.

Lo C.F., Ho C.H., Chen C.H., Liu K.F., Chiu Y.L., Yeh P.Y., Peng S.E., Hsu H.C., Liu H.C., Chang C.F., Su M.S., Wang C.H. \& Kou G.H. (1997) Detection and tissue tropism of white spot syndrome baculovirus (WSBV) in captured brooders of Penaeus monodon with a special emphasis on reproductive organs. Diseases of Aquatic Organisms 30, 53-72.

Lo C.F., Hsu H.C., Tsai M.F., Ho C.H., Peng S.E., Kou G.H. \& Lightner D.V. (1999) Specific genomic DNA fragment analysis of different geographical clinical samples of shrimp white spot syndrome virus. Diseases of Aquatic Organisms 35, 175-185.

Lotz J.M. \& Soto A.M. (2002) Model of white spot syndrome virus (WSSV) epidemics in Litopenaeus vannamei. Diseases of Aquatic Organisms 50, 199-209.

Lu Y., Tapay L.M., Loh P.C., Gose R.B. \& Brock J.A. (1997) The pathogenicity of a baculo-like virus isolated from diseased penaeid shrimp obtained from China for cultured penaeid species in Hawaii. Aquaculture International 5, 277-282.

Lua L.H. \& Reid S. (2000) Virus morphogenesis of Helicoverpa armigera nucleopolyhedrovirus in Helicoverpa zea serum-free suspension culture. Journal of General Virology 81, 2531-2543.

Magbanua F.O., Natividad K.T., Migo V.P., Alfafara C.G., de la Peña F.O., Miranda R.O., Albaladejo J.D., Nadala E.C.B., Loh P.C. \& Tapay L.M. (2000) White spot syndrome virus (WSSV) in cultured Penaeus monodon in the Philippines. Diseases of Aquatic Organisms 42, 77-82.

Marks H. (2005) Genomics and Transcriptomics of White Spot Syndrome Virus. PhD dissertation, Department of Plant Sciences, Wageningen University, The Netherlands.

Mazid M.A. \& Banu A.N.H. (2002) An overview of the social and economic impact and management of fish and shrimp
(C) 2008 The Authors. Journal compilation (C) 2008 Blackwell Publishing Ltd 
disease in Bangladesh, with an emphasis on small-scale aquaculture. In: Primary Aquatic Animal Health Care in Rural, Small-Scale Aquaculture Development (ed. by J.R. Arthur, M.J. Phillips, R.P. Subasinghe, M. Bondad-Reantaso \& I.H. Macrae), pp. 21-25. FAO Fisheries Technical Paper 406, FAO, Rome, Italy.

Nadala E.C.B. \& Loh P.C. (1998) A comparative study of three different isolates of white spot virus. Diseases of Aquatic Organisms 33, 231-234.

Nadala E.C.B. \& Loh P.C. (2000) Dot-blot nitrocellulose enzyme immunoassays for the detection of white-spot virus and yellow-head virus of penaeid shrimp. Journal of Virological Methods 84, 175-179.

Nadala E.C.B., Tapay L.M. \& Loh P.C. (1998) Characterization of a non-occluded baculovirus-like agent pathogenic to penaeid shrimp. Diseases of Aquatic Organisms 33, 221-229.

Otta S.K., Shubha G., Joseph B., Chakraborty A., Karunasagar I. \& Karunasagar I. (1999) Polymerase chain reaction (PCR) detection of white spot syndrome virus (WSSV) in cultured and wild crustaceans in India. Diseases of Aquatic Organisms 38, 67-70.

Park J.H., Lee Y.S., Lee S. \& Lee Y. (1998) An infectious viral disease of penaeid shrimp newly found in Korea. Diseases of Aquatic Organisms 34, 71-75.

Poulos B.T., Pantoja C.R., Bradley-Dunlop D., Aguilar J. \& Lightner D.V. (2001) Development and application of monoclonal antibodies for the detection of white spot syndrome virus of penaeid shrimp. Diseases of Aquatic Organisms 47, 13-23.

Pramod-Kiran R., Rajendran K., Jung S. \& Oh M. (2002) Experimental susceptibility of different life-stages of the giant freshwater prawn Macrobrachium rosenbergii (de Man), to white spot syndrome virus (WSSV). Journal of Fish Diseases 25, 201-207.

Rajan P.R., Ramasamy P., Purushothaman V. \& Brennan G.P. (2000) White spot baculovirus syndrome in the Indian shrimp Penaeus monodon and P. indicus. Aquaculture 184, 31-44.

Rajendran K.V., Vijayan K.K., Santiago T.C. \& Krol R.M. (1999) Experimental host range and histopathology of white spot syndrome virus (WSSV) infection in shrimp, prawns, crayfish and lobsters from India. Journal of Fish Diseases 22, 183-191.

Rajendran K.V., Mukherjee S.C., Vijayan K.K., Jung S.J., Kim Y.J. \& Oh M.J. (2004) A comparative study of white spot syndrome virus infection in shrimp from India and Korea. Journal of Invertebrate Pathology 84, 173-176.

Ramírez-Douriet C., De Silva-Dávila R., Méndez-Lozano J., Escobedo-Urias D., Leyva-Arana I. \& López-Meyer M. (2005) White spot syndrome virus detection in zooplankton of coastal lagoons and shrimp commercial ponds in Sinaloa, Mexico. In: 135th Annual Meeting of the American Fisheries $S$ (ed. by The American Fisheries Society), poster. Anchorage, Alaska.

Raoult D., Audic S., Robert C., Abergel C., Renesto P., Ogata H., La Scola B., Suzan M. \& Claverie J.-M. (2004) The 1.2-megabase genome sequence of mimivirus. Science 306, 1344-1350.

Robalino J., Bartlett T., Shepard E.F., Prior S., Jaramillo G., Scura E., Chapman R.W., Gross P.S., Browdy C.L. \& Warr (C) 2008 The Authors. G.W. (2005) Double-stranded RNA induces sequence-specific antiviral silencing in addition to non-specific immunity in marine shrimp: convergence of RNA interference and innate immunity in the invertebrate antiviral response? Journal of Virology 79, 13561-13571.

Rosenberry B. (2001) World shrimp farming 2000. In: Shrimp News International, USA (ed. by B. Rosenberry), pp. 324. Shrimp News International, San Diego, CA, USA.

Sahul-Hameed A.S., Anilkumar M., Raj M.L.S. \& Jayaraman K. (1998) Studies on the pathogenicity of systemic ectodermal and mesodermal baculovirus and its detection in shrimp by immunological methods. Aquaculture 160, 31-45.

Sahul-Hameed A.S., Charles M.X. \& Anilkumar M. (2000) Tolerance of Macrobrachium rosenbergii to white spot syndrome virus. Aquaculture 183, 207-213.

Sahul-Hameed A.S., Yoganandhan K., Sathish S., Rasheed M., Murugan V. \& Jayaraman K. (2001) White spot syndrome virus (WSSV) in two species of freshwater crabs (Paratelphusa hydrodomus and P. pulvinata). Aquaculture 201, 179-186.

Sahul-Hameed A.S., Balasubramanian G., Syed Musthaq S. \& Yoganandhan K. (2003) Experimental infection of twenty species of Indian marine crabs with white spot syndrome virus (WSSV). Diseases of Aquatic Organisms 57, 157-161.

Shi Z., Huang C., Zhang J., Chen D. \& Bonami J.R. (2000) White spot syndrome virus (WSSV) experimental infection of the freshwater crayfish Cherax quadricarinatus. Journal of Fish Diseases 23, 285-288.

Shi Z., Wang H., Zhang J., Xie Y., Li L., Chen X., Edgerton B.F. \& Bonami J.R. (2005) Response of crayfish, Procambarus clarkii, haemocytes infected by white spot syndrome virus. Journal of Fish Diseases 28, 151-156.

Shih H.H., Wang C.S., Tan L.F. \& Chen S.N. (2001) Characterization and application of monoclonal antibodies against white spot syndrome virus. Journal of Fish Diseases 24, 143 150.

Sritunyalucksana K., Wannapapho W., Lo C.F. \& Flegel T.W. (2006) PmRab7 is a VP28-binding protein involved in white spot syndrome virus infection in shrimp. Journal of Virology 80, 10734-10742.

Supak L.S., Boonnat A., Poltana P., Kanchanaphum P., Gangnonngiw W., Nash G. \& Withyachumnarnkul B. (2005) Infectivity of white spot syndrome virus (WSSV) to the polychaete Pereneis nuntia and a possibility of WSSV transmission from the polychaete to the black tiger shrimp Penaeus monodon. In: Diseases in Asian Aquaculture V (ed. by P.J. Walker, R. Lester \& M.G. Bondad-Reantaso), pp. 353-361. Fish Health Section, Asian Fisheries Society, Manila, Philippines.

Supamattaya K., Hoffman R.W., Boonyaratpalin S. \& Kanchanaphum P. (1998) Experimental transmission of white spot syndrome virus (WSSV) from black tiger shrimp Penaeus monodon to the sand crab Portunus pelagicus, mud crab Scylla serrata and krill Acetes sp. Diseases of Aquatic Organisms 32, $79-85$.

Takahashi Y., Kondo M., Itami T., Honda T., Inagawa H., Nishizawa T., Soma G.I. \& Yokomiso Y. (2000) Enhancement of disease resistance against penaeid acute viraemia and induction of virus-inactivating activity in haemolymph of kuruma shrimp, Penaeus japonicus, by oral administration of
Journal compilation

(C) 2008

Blackwell Publishing Ltd 
Pantoea agglomerans lipopolysaccharide (LPS). Fish \& Shellfish Immunology 10, 555-558.

Tsai M.F., Lo C.F., Van Hulten M.C.W., Tzeng H.F., Chou C.M., Huang C.J., Wang C.H., Lin J.Y., Vlak J.M. \& Kou G.H. (2000a) Transcriptional analysis of the ribonucleotide reductase genes of shrimp white spot syndrome virus. Virology 277, 92-99.

Tsai M.F., Yu H.T., Tzeng H.F., Leu J.H., Chou C.M., Huang C.J., Wang C.H., Lin J.Y., Kou G.H. \& Lo C.F. (2000b) Identification and characterization of a shrimp white spot syndrome virus (WSSV) gene that encodes a novel chimeric polypeptide of cellular-type thymidine kinase and thymidylate kinase. Virology 277, 100-110.

Tsai J.M., Wang H.C., Leu J.H., Hsiao H.H., Wang A.H.J., Kou G.H. \& Lo C.F. (2004) Genomic and proteomic analysis of thirty-nine structural proteins of shrimp white spot syndrome virus. Journal of Virology 78, 11360-11370.

Tsai J.M., Wang H.C., Leu J.H., Wang A.H.J., Zhuang Y., Walker P.J., Kou G.H. \& Lo C.F. (2006) Identification of the nucleocapsid, tegument and envelope proteins of the shrimp white spot syndrome virus virion. Journal of Virology 80, 3021-3029.

Venegas C.A., Nonaka L., Mushiake K., Nishizawa T. \& Muroga K. (2000) Quasi-immune response of Penaeus japonicus to penaeid rod-shaped DNA virus (PRDV). Diseases of Aquatic Organisms 42, 83-89.

Vijayan K.K., Stalin Raj V., Balasubramanian C.P., Alavandi S.V., Thillai Sekhar V. \& Santiago T.C. (2005) Polychaete worms - a vector for white spot syndrome virus (WSSV). Diseases of Aquatic Organisms 63, 107-111.

Vlak J.M., Bonami J.R., Flegel T.W., Kou G.H., Lightner D.V., Lo C.F., Loh P.C. \& Walker P.J. (2005) Nimaviridae. In: Virus Taxonomy VIIIth Report of the International Committee on Taxonomy of Viruses (ed. by C.M. Fauquet, M.A. Mayo, J. Maniloff, U. Desselberger \& L.A. Ball), pp. 187-192. Elsevier/Academic Press, London.

Wang C.H., Lo C.F., Leu J.H., Chou C.M., Yeh P.Y., Chou H.Y., Tung M.C., Chang C.F., Su M.S. \& Kou G.H. (1995) Purification and genomic analysis of baculovirus associated with white spot syndrome (WSBV) of Penaeus monodon. Diseases of Aquatic Organisms 23, 239-242.

Wang Y.C., Lo C.F., Chang P.S. \& Kou G.H. (1998a) Experimental infection of white spot baculovirus in some cultured and wild decapods in Taiwan. Aquaculture 164, 221-231.

Wang C.S., Tsai Y.J. \& Chen S.N. (1998b) Detection of white spot disease virus (WSDV) infection in shrimp using in situ hybridization. Journal of Invertebrate Pathology 72, 170-173.

Wang Y.G., Hassan M.D., Shariff M., Zamri S.M. \& Chen X. (1999a) Histopathology and cytopathology of white spot syndrome virus (WSSV) in cultured Penaeus monodon from peninsular Malaysia with emphasis on pathogenesis and the mechanism of white spot formation. Diseases of Aquatic Organisms 39, 1-11.

Wang Q., White B.L., Redman R.M. \& Lightner D.V. (1999b) Per os challenge of Litopenaeus vannamei postlarvae and Farfantepenaeus duorarum juveniles with six geographic isolates of white spot syndrome virus. Aquaculture 170, 179-194.
Wang Q., Poulos B.T. \& Lightner D.V. (2000) Protein analysis of geographic isolates of shrimp white spot syndrome virus. Archives of Virology 145, 263-274.

Wang Y.T., Liu W., Seah J.N., Lam C.S., Xiang J.H., Korzh V. \& Kwang J. (2002) White spot syndrome virus (WSSV) infects specific hemocytes of the shrimp Penaeus merguiensis. Diseases of Aquatic Organisms 52, 249-259.

Wang B., Li F., Dong B., Zhang X., Zhang C. \& Xiang J. (2006) Discovery of the genes in response to white spot syndrome virus (WSSV) infection in Fenneropenaeus chinensis through cDNA microarray. Marine Biotechnology 8, 491-500.

Wang H.C., Wang H.C., Leu J.H., Kou G.H., Wang A.H.J. \& Lo C.F. (2007) Protein expression profiling of the shrimp cellular response to white spot syndrome virus infection. Developmental and Comparative Immunology, 31, 672-686.

Witteveldt J., van Hulten M.C.W. \& Vlak J.M. (2001) Identification and phylogeny of a non-specific endonuclease gene of white spot syndrome virus of shrimp. Virus Genes, 23, 331337.

Wongteerasupaya C., Vickers J.E., Sriurairatana S., Nash G.L., Akarajamorn A., Boonsaeng V., Panyim S., Tassanakajon A., Withyachumnarnkul B. \& Flegel T.W. (1995) A non-occluded, systemic baculovirus that occurs in cells of ectodermal and mesodermal origin and causes high mortality in the black tiger prawn Penaeus monodon. Diseases of Aquatic Organisms 21, 69-77.

Wongteerasupaya C., Wongwisansri S., Boonsaeng V., Panyim S., Pratanpipat P., Nash G.L., Withyachumnarnkul B. \& Flegel T.W. (1996) DNA fragment of Penaeus monodon baculovirus PmNOBII gives positive in situ hybridization with white-spot viral infections in six penaeid shrimp species. Aquaculture 143, 23-32.

Wongteerasupaya C., Pungchai P., Withyachumnarnkul B., Boonsaeng V., Panyim S., Flegel T.W. \& Walker P.J. (2003) High variation in repetitive DNA fragment length for white spot syndrome virus (WSSV) isolates in Thailand. Diseases of Aquatic Organisms 54, 253-257.

Wu C. \& Yang F. (2006) Localization studies of two white spot syndrome virus structural proteins VP51 and VP76. Virology Journal 3, 76-83.

Wu J.L., Namikoshi A., Nishizawa T., Mushiake K., Teruya K. \& Muroga K. (2001) Effects of shrimp density on transmission of penaeid acute viremia in Penaeus japonicus by cannibalism and the waterborne route. Diseases of Aquatic Organisms 47, 129-135.

Wu W., Wang L. \& Zhang X. (2005) Identification of white spot syndrome virus (WSSV) envelope proteins involved in shrimp infection. Virology 332, 578-583.

Xiao N., Zhang X., Dai L., Yuan L., Wang Y., Zhang M., Xu T. \& Dai H. (2006) Isolation and identification of a novel WSSV nucleocapsid protein by cDNA phage display using an $s \mathrm{cFv}$ antibody. Journal of Virological Methods 137, 272-279.

Xie X. \& Yang F. (2005) Interaction of white spot syndrome virus VP26 protein with actin. Virology 336, 93-99.

Xie X. \& Yang F. (2006) White spot syndrome virus VP24 interacts with VP28 and is involved in virus infection. Journal of General Virology 87, 1903-1908.
(C) 2008 The Authors. Journal compilation (C) 2008 Blackwell Publishing Ltd 
Xie X., Xu L. \& Yang F. (2006) Proteomic analysis of the major envelope and nucleocapsid proteins of white spot syndrome virus. Journal of Virology 80, 10615-10623.

Xu J., Han F. \& Zhang X. (2007) Silencing shrimp white spot syndrome virus (WSSV) genes by siRNA. Antiviral Research 73, 126-131.

Yan D.C., Dong S.L., Huang J., Yu X.M. \& Feng M.Y. (2004) White spot syndrome virus (WSSV) detected by PCR in rotifers and rotifer resting eggs from shrimp pond sediments. Diseases of Aquatic Organisms 59, 69-73.

Yan D.C., Dong S.L., Huang J. \& Zhang J.S. (2007) White spot syndrome virus (WSSV) transmission from rotifer inoculum to crayfish. Journal of Invertebrate Pathology 94, 144-148.

Yang F., He J., Lin X., Li Q., Pan D., Zhang X. \& Xu X. (2001) Complete genome sequence of the shrimp white spot bacilliform virus. Journal of Virology 75, 11811-11820.

Yi G., Wang Z., Qi Y., Yao L., Qian J. \& Hu L. (2004) VP28 of shrimp white spot syndrome virus is involved in the attachment and penetration into shrimp cells. Journal of Biochemistry and Molecular Biology 37, 726-734.

Yoganandhan K., Syed Musthaq S., Narayanan R.B. \& Sahul Hameed A.S. (2004) Production of polyclonal antiserum against recombinant VP28 protein and its application for the detection of white spot syndrome virus in crustaceans. Journal of Fish Diseases 27, 517-522.

You Z., Nadala C.E.B., Yang J., van Hulten M.C.W. \& Loh P.C. (2002) Production of polyclonal antiserum specific to the $27.5 \mathrm{kDa}$ envelope protein of white spot syndrome virus. Diseases of Aquatic Organisms 51, 77-80.

Zhan W.B., Wang Y.H., Fryer J.L., Yu K.K., Fukuda H. \& Meng Q.X. (1998) White spot syndrome virus infection of cultured shrimp in China. Journal of Aquatic Animal Health 10, 405-410.
Zhan W., Wang X., Chen J., Xing J. \& Fukuda H. (2004) Elimination of shrimp endogenous alkaline phosphatase background and development of enzyme immunoassays for the detection of white spot syndrome virus (WSSV). Aquaculture 239, 15-21.

Zhang X., Xu L. \& Xu X. (2001) Detection of prawn white spot bacilliform virus by immunoassay with recombinant antigen. Journal of Virological Methods 92, 193-197.

Zhang X., Huang C., Tang X., Zhuang Y. \& Hew C.L. (2004) Indentification of structural proteins from shrimp white spot syndrome virus (WSSV) by 2DE-MS. Proteins: Structure, Function and Bioinformatics 55, 229-235.

Zhao Z.Y., Yin Z.X., Weng S.P., Guan H.J., Li S.D., Xing K., Chan S.M. \& He J.G. (2007) Profiling of differentially-expressed genes in the hepatopancreas of white spot syndrome virus-resistant shrimp (Litopenaeus vannamei) by suppression substractive hybridization. Fish \& Shellfish Immunology 22, 520-534.

Zhu Y., Xie X. \& Yang F. (2005) Transcription and identification of a novel envelope protein (VP124) gene of shrimp white spot syndrome virus. Virus Research 113, 100-106.

Zhu Y.B., Li H.Y. \& Yang F. (2006) Identification of an envelope protein (VP39) gene from white spot syndrome virus. Archives of Virology 151, 71-82.

Zhu Y., Ding Q. \& Yang F.. (2007) Characterization of a homologous-region-binding protein from white spot syndrome virus by phage display. Virus Research 125, 145 152.

Received: 5 January 2007

Revision revised: 26 May 2007

Accepted: 5 June 2007
(C) 2008 The Authors. Journal compilation (C) 2008 Blackwell Publishing Ltd 